\title{
TV/Series
}

18 | 2020

Séries et espace

\section{The phonology of the Northern, the Southern and the foreign in Game of Thrones}

\section{Cécile Viollain and Hugo Chatellier}

\section{(2) OpenEdition \\ Journals}

\section{Electronic version}

URL: http://journals.openedition.org/tvseries/4508

DOI: $10.4000 /$ tvseries.4508

ISSN: 2266-0909

\section{Publisher}

GRIC - Groupe de recherche Identités et Cultures

\section{Electronic reference}

Cécile Viollain and Hugo Chatellier, «The phonology of the Northern, the Southern and the foreign in Game of Thrones », TV/Series [Online], 18 | 2020, Online since 15 September 2020, connection on 08 December 2020. URL : http://journals.openedition.org/tvseries/4508 ; DOI : https://doi.org/10.4000/ tvseries.4508

This text was automatically generated on 8 December 2020 .

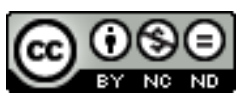

$T V /$ Series est mis à disposition selon les termes de la licence Creative Commons Attribution - Pas d'Utilisation Commerciale - Pas de Modification 4.0 International. 


\title{
The phonology of the Northern, the Southern and the foreign in Game of Thrones
}

\author{
Cécile Viollain and Hugo Chatellier
}

\section{Introduction - a Game of Phones?}

1 Let us state at the outset that we are not TV series specialists. We are corpus phonologists working within the framework of the French PAC programme $^{2}$ on the phonetic, phonological and sociolinguistic description of the varieties of English spoken worldwide based on authentic oral data. However, we are not immune to the addictive power of a good TV series and suffer from an acute case of professional hazard, which consists in compulsively commenting on actors and actresses' accent performances. Needless to say that it did not take long for us to fall into the Game of Thrones (HBO, 2011-19, henceforth GoT) trap and rejoice at its linguistic complexity.

2 No TV series had ever excited our ear in such a way before, except maybe for Misfits (E4, 2009-13) on a smaller scale or The Lord of the Rings and The Hobbit trilogies (2001-03 \& 2012-14) in the movie category. That makes perfect sense given the diversity of the cast which, on the GoT official website, includes 88 actors and actresses from very different geographical origins playing characters who belong to various houses and lineages ${ }^{3}$.

What is more, we have recently engaged in a reflection on "the Norths" in the Englishspeaking world, i.e. the stylistic representations of Northern identities in literary and audiovisual productions. In that respect, GoT also offers relevant material if we just consider cult lines such as "The King in the North", "Winter is coming" or "The North remembers". Indeed, since Sean Bean as Eddard Stark in season 1, GoT has put forward a specific vision of Northernness, as we shall analyze later on ( $\$ 3.3 \& 4)$.

When we started our reflection on "series and space", we immediately thought of the opening credits, which have undeniably become part and parcel of the GoT identity, while they were criticized at first for their length and apparent redundancy ${ }^{5}$. They 
enable viewers to navigate the narrative world of the series and have actually gained in minutia season after season, along with the viewers' knowledge of the storylines and territories. It is rather striking if one compares the opening credits for season $1^{6}$ to those for season $8^{7}$ : the map is no longer there to introduce the GoT universe but rather to summarize how the tectonics of the houses and armies have evolved. We therefore agree with Tzanelli ${ }^{8}$ that GoT is a "game of sites / sights" but are convinced that GoT is also a "game of phones" (in the phonetic sense of the term), which can make for a stimulating sociolinguistic case study since accents are metonymically used to diagnose people's geographical origins and social profiles.

5 Yet, when we entered "accents in Game of Thrones" on Google and hit more than 10 million results, we feared that we might have missed the action, and thought we would discover rich literature on the subject. The truth is that most of the listed resources consist in lay accounts of the actors and actresses' accent performances, which generally do not adopt a descriptive approach but rather a comfortably prescriptive stance, as in Mashable's "Why the accents in Game of Thrones make no sense" for example. There are a few Master's theses which we shall refer to when relevant, notably Lien ${ }^{10}$, but no scientific article articulating a socio-phonological analysis of the accents performed in the series. We hope that our proposal can start filling this gap.

6 As we started working on this contribution, we began to fully appreciate how challenging the GoT corpus is and why such studies are seldom found in the literature. With 8 seasons, 73 episodes and more than 4,000 minutes of TV show, there is overabundant material, but studying it with a corpus-based approach can soon prove nightmarish from a methodological perspective. Indeed, most of the show's speech comes with music, which makes phonetic-acoustic analyses, notably of vowel formant values, impossible. Our study will thus be more qualitative and rely on auditory microanalyses of specific scenes so as to illustrate the phenomena the series showcases and its characteristic sociolinguistic motifs.

\section{Outline}

7 In order to assess to what extent GoT is a "linguistic show" 11 and how accurately it finds its way through the complex system dynamics of accents, especially in England, we shall focus first on its "topofocal" dimension (\$2). Its storyline relies on a North/South divide which makes characters' accents a necessary attribute. Indeed, the theme of the North necessarily conjures that of the South, of the border, of civilization and of foreignness. We shall also discuss the intrinsic phonological hybridity of the show, which is often described as "Mid-Atlantic" since it is aired on HBO primarily for an American audience but casts a majority of British actors who perform accents that are not necessarily their own in real life. This has sparked a lot of comments on the seemingly chaotic and shattered linguistic world of the series ${ }^{12}$.

8 We shall then detail the phonological and phonetic characteristics that are retained to distinguish the Northern from the Southern and the foreign ( $\$ 3)$. In doing so, we will point out the successes and the inconsistencies in some of the main characters' accent performances and in the creators' linguistic choices. This should finally allow us to reflect on the paradoxical basis for stereotyping, i.e. the fact that it bears some truth as speakers are able to pinpoint other people's geographical and social origins based on how they speak (so why not use this sociolinguistic skill in TV series?), but also some 
oversimplifications and misrepresentations which break away from scientific facts. We will therefore agree with Lundervold that GoT is an intricate "game of attitudes ${ }^{13}$ ".

In the end, what is at stake when mapping out GoT's specific world, which has made the fantasy genre almost mainstream ${ }^{14}$, is the balance between linguistic authenticity and the necessary stereotypes the audience can relate to $(\$ 4)$. When we talk about a chaotic linguistic universe, we argue that we should be talking about a difficult compromise between performed and actual accents which, we think, the series handles quite well.

\section{A "topofocal" and linguistic show}

10 In this section, we will establish the link between the focus on spaces that is characteristic of fantasy in general, and of GoT in particular, and the use of languages and accents as necessary attributes in fleshing out its characters, which makes of the TV series adaptation a hybrid object, both original and familiar.

\subsection{What is Game of Thrones?}

Let us start by explaining what GoT is - for those who might have been living on a desert island for the past decade. This massively popular TV series phenomenon, created by David Benioff and D.B. Weiss, has been aired on HBO since 2011, climaxing in 2019 with 19.3 million people watching its final episode, which broke the network's record $^{15}$. More generally, GoT is the recipient of $38 \mathrm{Emmy}$ Awards, is literally watched all over the world, i.e. in more than 170 countries, and has become the most illegally downloaded show ${ }^{16}$. It is adapted from the bestselling book series A Song of Ice and Fire written by G.R.R. Martin, whose first volume, entitled A Game of Thrones, has (to the exclusion of the indefinite article) given its name to the TV series adaptation.

In fact, the first season faithfully gives life to the plot from the original fantasy novel, which should not come as a surprise given that Martin is an executive producer on the show. It can be summarized as follows: on the continent of Westeros, there are four main houses - the Baratheons, the Targaryens, the Lannisters and the Starks. When the series begins, Robert Baratheon has been sitting on the Iron Throne in the Westerosi capital, King's Landing, for nine years since "The Mad King's" (Aerys Targaryen) murder by Jaime Lannister, following Robert's rebellion, and the subsequent downfall of the Targaryens ${ }^{17}$. The two surviving Targaryen children, Viserys and Daenerys, live in exile in Essos, the continent east of Westeros. Robert Baratheon is married to Cersei Lannister while Jaime Lannister, her twin brother, serves in the King's Guard. When Robert's Hand of the King (most-trusted advisor) dies, he goes North where his childhood friend, Eddard "Ned" Stark, Lord of Winterfell, serves as Warden of the North. Robert names him the new Hand and commands him to come with him South to King's Landing. Ned reluctantly agrees and, as he is preparing to leave for the capital, the audience discovers that the Lannister twins take a very dim view of his arrival in the South and engage in machinations in order to keep control over the throne and hide an extremely weighty secret. From that first episode onwards, betrayals, deaths, battles, tremendous reveals and as many cliffhangers ensue, as the game of power and deceit unfolds. 


\subsection{Space and places}

13 And from the first episode onwards, a crucial accent (if you can forgive our indulging in wordplay here) is put on space and places, as Hassler-Forest ${ }^{18}$ makes perfectly clear, relying on Stefan Ekman's concept of "topofocal approach"19":

One of the generic features of the fantasy genre that has been left intact both in Martin's novels and in the TV adaptation is the strong emphasis on the mapping of imaginary geographical spaces, as is so often the case with "secondary worlds". With many varieties of high fantasy literature, one is all but forced to keep the accompanying maps handy while reading, as one's understanding of the narrative is mostly predicated on the ability to follow the characters' trajectories through this fictitious geography. In many fantasy franchises devoted to the development of imaginary worlds, this emphasis on mapping out the diegetic environment shifts the audience's focus from the narrative's causal chain to the complex environment that sustains it, something Stefan Ekman refers to as a "topofocal" - or placecentric - approach, in which "setting is as important as character and plot". (our emphases)

14 As a matter of fact, one of the essential resources on the official HBO viewers' guide is a map of the GoT universe ${ }^{20}$, which the viewer can navigate as on Google Maps. This actually gave one fan the idea to map out the GoT world according to the Google Maps standards ${ }^{21}$, as can be seen in figure 1, in which we circled King's Landing, the capital, and Winterfell, the Starks' home, as points of reference since these are the two fundamental needles on the Westerosi compass.

However, G.R.R. Martin did not stop at two places when creating the GoT universe, which includes Seven Kingdoms and consequently many areas of interest - among which, the Wall that separates civilization from the Free Folk, the Wildlings who live north of it, and from the ominous and imminent arrival of the White Walkers. King's Landing is not the southernmost site in Westeros since the Stormlands, Oldtown and Dorne, for example, are located further south. Westeros is not even the only continent on the map, as it is separated from Essos by the Narrow Sea. So GoT's fictitious geography covers a large territory with many inner borders and thus forms a territorial continuum in which the notions of North and South, and even of West and East, if we consider one of Arya Stark's final lines ("What is west of Westeros?", S08E06), are necessarily relative.

Figure 1: Google map of the GoT world 


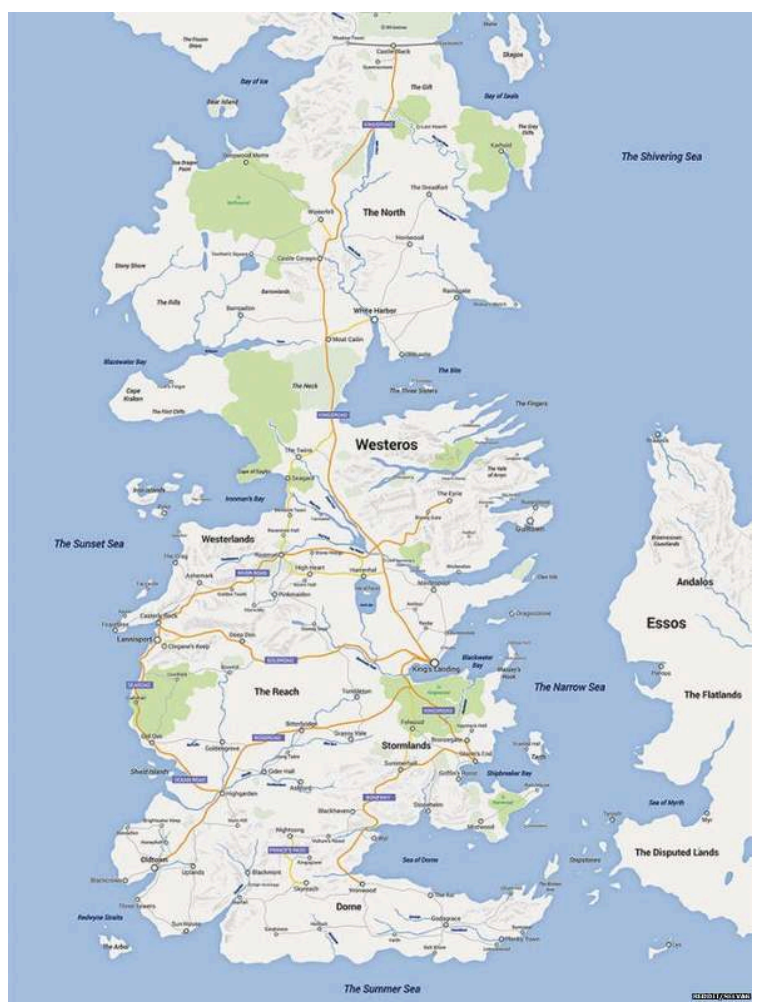

17 Moreover, distances between places are of paramount importance in the show as they chronologically frame it (to the exception of the last two seasons which have worked on a much-accelerated rhythm): after all, it took Daenerys Targaryen 7 seasons to reach King's Landing for instance. Sense of place and sense of time are therefore interconnected in GoT, which we shall detail further when studying its inspirations (§2.3), its linguistic dimension (\$2.4) and the accents spoken by its characters (\$3).

Hence the pressure on the showrunners for the pilot season as it was meant to introduce GoT's fantasy world to beginners but also to live up to the expectations of the fans who had read and enjoyed the novels. It was on the basis of that first season that die-hard fans would decide whether the TV series adaptation betrayed Martin's original work or brought something more to the story of the Seven Kingdoms, but also that beginners would choose to explore that new universe or switch channels. In other words, much is at stake in terms of giving body to both places and people, as nothing is left to imagination anymore and one single version is presented to the viewer. Bearing that in mind, choices in terms of cast, fashion, shooting locations and, we argue, languages and accents, prove decisive and, above all, permanent.

Visually, GoT is introduced as both unknown and familiar, fantastic and ordinary, as Wells-Lassagne ${ }^{22}$ explains:

The most striking thing about the opening of Game of Thrones is the silence, the solemnity with which it begins - clearly this is a series that is going to take its time setting the scene before advancing the action. The opening image of faces behind a gate initially show little difference from our own universe, and though we then see them dressed in medieval garb and on horseback, the defamiliarisation is minimal: they are not dressed gaudily, or in hose and doublet, or even stylishly, in leather catsuits à la Xena - these are dark, practical clothes, quite similar to our own when attempting to stay 
warm. Though this is clearly not our world, it is a recognizable one. (our emphases)

\subsection{A Mid-Atlantic production with a hybrid identity?}

20 In fact, in several interviews, notably with the Huffington Post ${ }^{23}$ and the Guardian ${ }^{24}$, G.R.R Martin himself explained the genesis of his work: GoT depicting a pseudo-medieval era, the old Continent and the history of the Middle Ages provided kings, thrones, realms, conquests and legends. Among his main inspirations are fiction and historical facts, namely Maurice Druon's Les Rois Maudits ("The Accursed Kings", 1955-77) and Thomas B. Costain's A History of the Plantagenets in 4 volumes (1949-62).

21 So GoT is American because it has been aired on HBO, primarily for an American audience, because the original book series was written by an American and because both creators of the show are American. However, its roots and inspirations are fundamentally British, and more generally European.

In a 2013 interview ${ }^{25}$, Martin declared: "I'm fascinated by war", and it is the English Wars of the Roses in the fifteenth century between the red rose, the House of Lancaster, and the white rose, the House of York, which gave the inspiration for the antagonism between the lions, House Lannister and the dire wolves, House Stark. The more ancient history of England is also conjured with the invasion of the Andals ${ }^{26}$, clearly reminiscent of the Angles who gave their name to the England that we still know today. Alexander Nikolaev ${ }^{27}$ details this parallel further:

Basically, the history of Westeros is a mirror-image of the history of the British Isles: the original population of Westeros were the Children of the Forest, later ousted by the First People, who in turn had to move to the North when the Andals came along. Then came the Rhoynars, who took control over the southern part of the continent. Finally, with Aegon's Conquest, the era of Targaryens begins.

Now think of the British Isles: the mysterious Picts, whose artifacts are found in northern Scotland, may or may not have been the earliest inhabitants of Great Britain. They probably had to move to the north when people who spoke Celtic languages (today's Irish and Welsh and Scottish Gaelic) migrated from the continent. But Celts in turn had to move, first when the Romans came in the first century $\mathrm{CE}$ and then again when Great Britain was invaded from the continent by Germanic tribes (Angles, Saxons, and Jutes, collectively referred to as Anglo-Saxons) in the fifth century. And then of course there was the Norman conquest in 1066, with William the Conqueror being the prototype for Aegon, bringing new gods and new language to Westeros.

However, the inspiration is not only historical, it is also geographical as Martin confessed at Comic Con $2014^{28}$. Westeros started out as an upside-down replica of Ireland, as can be observed in figure 2. The North would be a mirror image of England and Wales, with Hadrian's Wall being the boundary between England and Scotland in the same way that the Wall separates civilization from the Wildlings and the White Walkers in the show.

Besides, the series was shot in many different locations, except in America: most of the interior and Northern scenes were shot in Northern Ireland as well as in Iceland (for the frozen lands beyond the Wall), while the Southern scenes (notably King's Landing 
and Dorne in Westeros as well as Slaver's Bay and Pentos in Essos) were shot in Croatia, Malta, Morocco and Spain.

25 Figure 2: the map of Westeros compared to the map of the British Isles

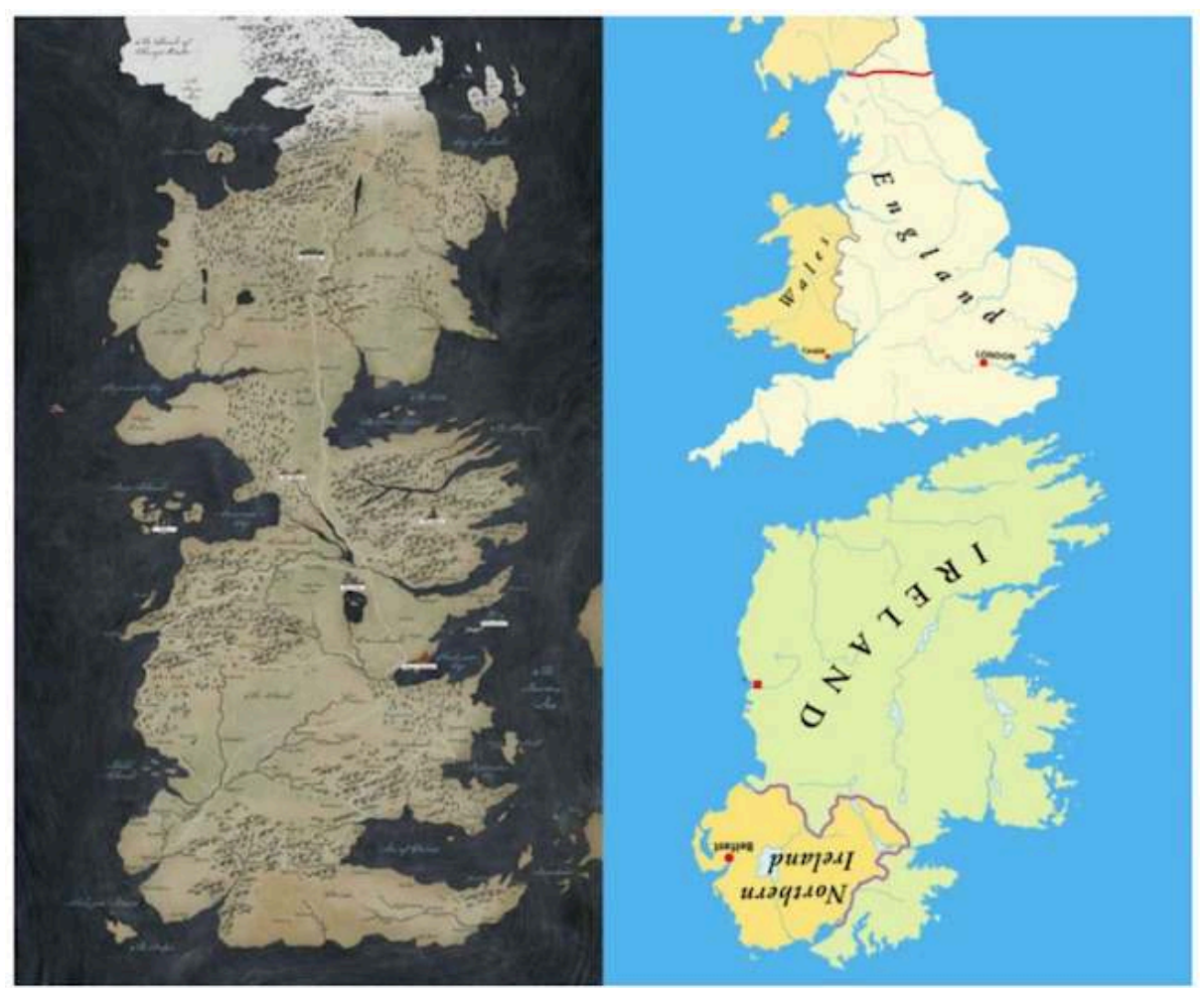

26 The series' identity then appears historically and geographically hybrid, as this American production is set in a world that reminds us of the British Isles but also includes exotic territories which use Mediterranean locations as their setting. GoT therefore seems to exist at the crossroads of several historical and geographical entities as a Mid-Atlantic production which is disorienting yet recognizable. The show then also exists at the crossroads of several linguistic identities, notably as this American production casts an overwhelming majority of British actors who perform different languages and accents.

\subsection{Languages and accents: a show of performances}

One could wonder why bother with languages and accents at all since GoT is fantasy anyway, and so "not our world" (\$2.2). But as G.R.R. Martin's books and its TV series adaptation are high fantasy, they inherit a long tradition of creating parallel universes where the people or creatures who inhabit those places usually speak their native tongues - a characteristic shared with the science fiction genre. It can be observed in Star Wars with Huttese, in Star Trek with Klingon, in Avatar with Na'vi and in The Lord of the Rings with the Elvish languages notably.

28 As a self-proclaimed fan of J.R.R. Tolkien - "it is no coincidence that he goes by "GRR" Martin, like 'JRR' Tolkien ${ }^{29}$ " - Martin mentions two languages in his books, Dothraki, notably spoken by Khal Drogo in season 1, and High Valyrian, the native tongue of the Targaryens. However, contrary to Tolkien, he did not develop the languages, leaving 
the creators of the TV series almost no choice but to work on coining them, as Nikolaev $^{30}$ points out:

The Dothraki and the High Valyrian heard on the show were invented by linguist David J. Peterson, who won a 2009 contest dreamed up by the Game of Thrones creators.

And as is the case in many fantasy and science fiction adaptations, English is usually the "lingua franca" that is used by most characters to communicate ( $\$ 3)$ : what is called "Galactic Basic" in Star Trek or "Common Tongue" in GoT. Consequently, GoT both sounds linguistically foreign, as it includes constructed languages that have never been spoken or heard before, and phonologically familiar as English is the dominant vernacular.

Besides, with the advent of dialect coaches, more attention has been paid in recent years to the depiction of accents in movies and TV series. Actors' and actresses' accent performances have become an integral part of their craft and have earned them the most prestigious awards, like Meryl Streep in The Iron Lady (2011) or, on the contrary, never-ending scorn like Kevin Costner in Robin Hood Prince of Thieves (1991) ${ }^{31}$.

31 It is therefore no longer unprecedented but expected of them to perform accents, and so we claim that this has necessarily influenced the accent choices in GoT. In the same way that the show is both fantastic and ordinary, that it is historically, geographically and aesthetically familiar and unknown, it is also linguistically close and distant, authentic and counterfeit. We therefore argue that a topofocal show is necessarily a linguistic show and that accents contribute, as much as places, costumes and sigils, to anchoring the show geographically and historically and to establishing identities.

To further make this point, let us have a look at two inaugural scenes from season 1 which introduce the viewer to the Starks in Winterfell (S01E01) ${ }^{32}$ on the one hand, and to the Lannisters in King's Landing (S01E03) ${ }^{33}$ on the other. The antagonism is made obvious throughout the pilot season in many complementary ways. First, physically, with all the Starks being dark-haired when the Lannisters are fair-haired, but also, in terms of sophistication, fashion and hair style, as the Starks notably wear furs and leather clothing whereas the people in King's Landing wear lighter garments. Similarly, Cersei appears with an intricate hairstyle at the Winterfell feast (S01E01) and Jaime Lannister is presented as a Prince Charming type knight, whereas Lady Stark and the Stark girls wear their hair down and Ned seems to have greasy hair. As far as climate and settings are concerned, the Starks' home appears rather modest and dull when the Red Keep looks impressive and appears in full sunlight with palm trees outside. In addition, the Starks are presented as spending much time outside, as hard-working, when Jaime Lannister appears inside, in the majestic Iron Throne room, absorbed by the mysteries of politics. But accents also materialize the North/South divide as can be heard during Jaime Lannister and Ned Stark's first exchange: the latter has a distinctly Northern pronunciation when the former performs a standard Southern British accent, as we shall detail in the next section.

So GoT is a show of accent performances, and here is a quick guide to the actor/ character pairs. Given the scope of this article, we will only mention the main characters we shall refer to later on (\$3).

Sean Bean, who plays Ned Stark, is from Sheffield, Yorkshire, in Northern England. Within House Stark, Richard Madden, who plays Robb, is also from the North, as he is 
from Scotland, and Michelle Farley, who plays Catelyn, is from Northern Ireland. On the contrary, Kit Harington, who plays Jon Snow, is from the South, from London, while the Stark children, Maisie Williams (Arya) and Isaac Hempstead-Wright (Bran), come from Southern England (Bristol and Surrey), and Sophie Turner (Sansa) from the East Midlands (Northampton).

Even more heterogeneity is to be found within House Lannister as it includes an American actor from New Jersey, Peter Dinklage who plays Tyrion, a Danish actor from Rudkøbing, Nicolaj Coster-Waldau who plays Jaime, an Irish actor from Cork, Jack Gleeson who plays Joffrey Baratheon, and an English actress from Somerset, Lena Headey who plays Cersei.

Given the North/South divide that motivates the plot as well as the apparent phonological hybridity the show is built on, what are GoT's phonetic and phonological governing principles?

As an article recalls ${ }^{34}$, Sean Bean's accent in the show was an after-thought during the read-through of the pilot season. It was not an initially conscious creative decision from the showrunners. So, of course, as we will be mostly talking about accent performances throughout this article, we shall bear this in mind as an intrinsic limitation to our analyses and focus, not so much on intent or control over said performances, but more on the recurrence of specific phonological and phonetic phenomena in the actors and actresses' accent targets.

\section{The phonetic, phonological and sociolinguistic characteristics of the Northern, the Southern and the foreign}

In this section, we shall detail the phonetic and phonological characteristics of the accents of English that allow the audience to identify the characters as Northerners, Southerners or foreigners. In doing so, we first need to acknowledge that GoT resorts to a common linguistic process - namely "replacement" - which Bleichenbacher ${ }^{35}$ defines as follows:
Even when the depicted story would realistically have taken place in a different linguistic setting, the language(s) are replaced by the base language of narration; in my case, English. [...] Throughout the history of artistic representations of language use, audiences and critics have mostly accepted this sacrifice of realism for the sake of comprehension. Still, a central task of narration in any texts with linguistic replacement is to prevent the reader or viewer from assuming that [...] the characters would really have spoken English [...], especially if mistaken assumptions about the sociolinguistic setting can result in serious misunderstandings of the narrative. (our emphases)

We claim that linguistic replacement is actually the very process that allows GoT to be anchored historically, to perform the North/South divide by showcasing the main panNorthern and pan-Southern phonetic and phonological characteristics of the accents spoken in England, and to trigger sociolinguistic evaluations of the characters' profiles. We will also show that "evocation", which is one of the strategies of linguistic replacement, allows the audience to identify foreigners, as it consists in suggesting that 
someone is not a native speaker of the Common Tongue used in the series. As Bleichenbacher ${ }^{36}$ explains:

In theory, evocation could appear on any level of linguistic analysis, but phonology (L2 accents) and lexis (code-switches into the other language for certain words or phrases) are clearly its preferred sites.

41 The latter comment supports our claim that accents are prominent tools in order to anchor the show at the historical, geographical and sociolinguistic levels.

\subsection{Anchoring the show historically}

As previously mentioned ( $\$ 2.2 \& 2.3$ ), sense of place and sense of time are deeply interconnected in the series, and accents greatly contribute to this as they bring the audience "back" to a pseudo-medieval era. In doing so, one single characteristic is necessary, when several will be at play to anchor the show geographically (\$3.2) namely non-rhoticity.

The varieties of English are generally divided into two main streams ${ }^{37}$ : the non-rhotic varieties on the one hand, and the rhotic varieties on the other. In the latter, an orthographic $<r>$ is pronounced whatever its position in the syllable, i.e. in onset position, as in red (['red]) $)^{38}$ as well as in coda position, as in bar (['ba:r]). In the former, $<\mathrm{r}>$ is only realized in onset position, so in red (['red]), but never in coda position, as in bar (['ba:]). The pronunciation variety that is nowadays considered standard in England, which originates from the South-East and which we shall refer to as "Standard Southern British English" ${ }^{39 "}$ (henceforth SSBE), is non-rhotic. On the contrary, "General American" (GA), the reference accent in the United States, is rhotic.

Today, most of the English territory is non-rhotic, as can be observed in figure 3, which presents the last remaining pockets of rhoticity (with an ' $r$ '). While one could easily assume that non-rhoticity has always been a characteristic of English in England, that is not the case at all. Historically, all the varieties of English were rhotic, but many of them have undergone, or are still undergoing, the process of derhoticization ${ }^{40}$, also called "loss of coda-r4".

Figure 3: Map of residual rhoticity in England ${ }^{42}$ 


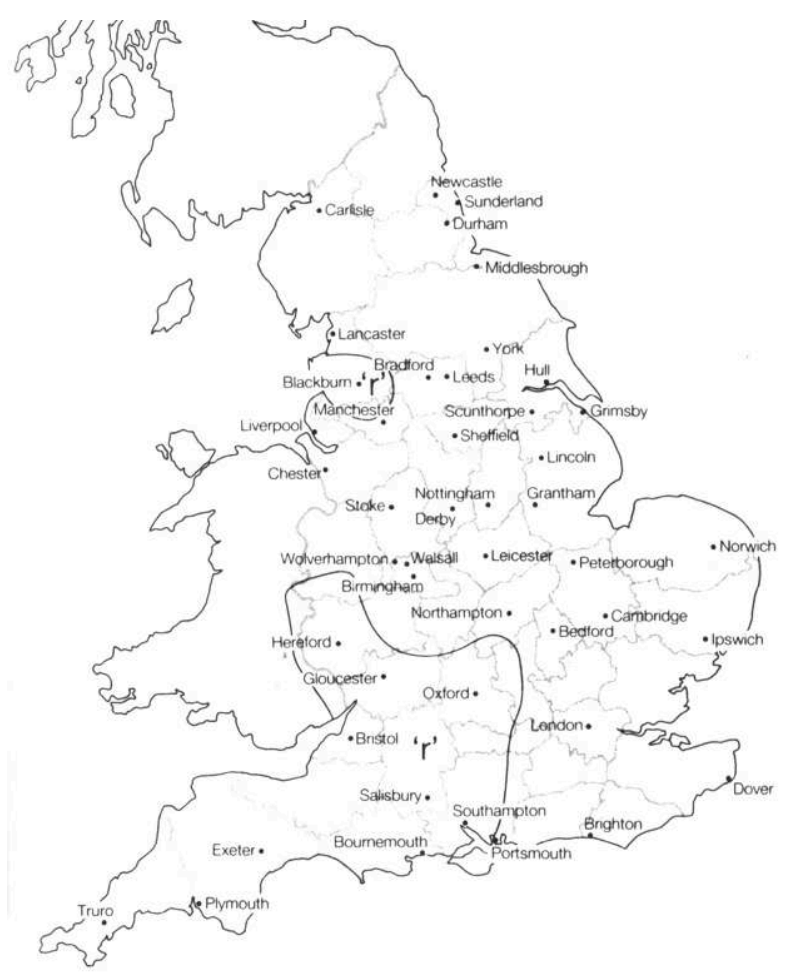

It is actually rather difficult to put a specific date on either the beginning or the completion of this process ${ }^{43}$, but some clues indicate the weakening of coda-r as early as the fifteenth century and testimonies, as well as the non-rhoticity of the earliest American colonies such as Boston for instance, suggest that derhoticization was already underway in the seventeenth century.

According to Lundervold ${ }^{44}$, whose study relies on 48 characters from the show, not a single one targets a variety characterized by rhoticity. As GoT is expected to bring us "back" to a pseudo-medieval era, this could amount to a crude linguistic anachronism. We argue that this kind of double linguistic replacement, which substitutes non-rhotic varieties - of English - to more historically accurate rhotic varieties, is used to anchor the show geographically by manifesting the British North/South divide to the audience's ears.

In doing so, it also moves past the "British as villain" cliché, which has been overwhelming in animated films ${ }^{45}$ but also in movies ${ }^{46}$, even in rather recent ones, as $\mathrm{Luu}^{47}$ humorously points out: "It's a linguistic truth universally acknowledged that any story worth telling must be in want of a very British villain." When Scar (The Lion King, 1994) had an SSBE accent while Simba had a GA accent, the phonological world of GoT appears more diverse, with more regional accents being featured (\$3.2), and refined, as most accents are British, which makes for more subtle differences between characters (\$3.3).

\subsection{Anchoring the show geographically}

As we saw previously (\$2), a clear antagonism between North and South is apparent in the way characters are depicted in GoT, and the situation of Westeros is in many respects akin to that of England, where the South enjoys a relatively prestigious status, from an economic, political, cultural and linguistic point of view, compared to the 
North. We shall therefore focus here on the major differences between the varieties spoken in the North of England and SSBE, or in other words, contrast the pan-Northern with the pan-Southern phonological and phonetic characteristics.

As a matter of fact, the "linguistic" North is hard to define precisely, because it does not strictly coincide with the "geographical" North. Wells ${ }^{48}$ argues in favour of the following definition:

I call everything from the Severn-Wash line northwards 'the (linguistic) north'. Within it we can distinguish, as we move away from London and towards the Scottish border, (i) the midlands, (ii) the middle north, and (iii) the far north.

51 As hinted at here, many different varieties are found in the linguistic North, and scholars have claimed that differences between varieties are sharper in the North than they are in the South ${ }^{49}$.

52 And yet, despite the linguistic complexity of the North, two features have traditionally been used to distinguish Northern from Southern varieties of British English: BATH ${ }^{50}$ broadening (a number of words that are pronounced with a short /æ/ vowel in the North are instead pronounced with a long /a:/ in the South, see figure 4) and the presence of a ғоОт/SтRUT opposition (also called "split") in the South (Northern varieties have a single $/ \mho /$ phoneme where Southern varieties have an opposition between $/ \mho /$ and $/ \Lambda /$, see figure 5 ). Historically, both features are innovations which arose in the South of England during the seventeenth century ${ }^{51}$.

Figure 4: BATH-broadening ${ }^{52}$

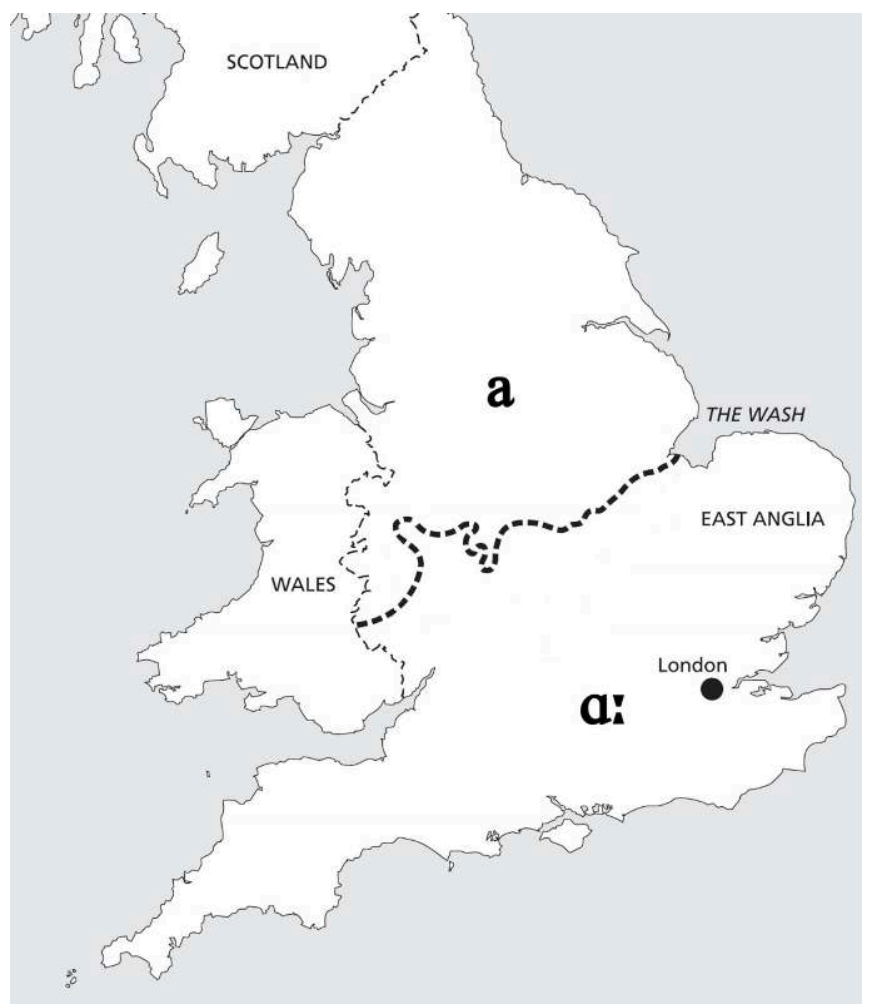

Nowadays, if a short /æ/ in BATH is often heard in Northern varieties across different social classes, the use of $/ \sigma /$ in STRUT is still associated with negative sociolinguistic evaluations, and is generally limited to the speech of working-class speakers: "broad 
working-class speakers certainly do not have any control of a FOOT vs. STRUT opposition, which is associated with 'good' speech only ${ }^{53}$ ".

Figure 5: Vowel of STRUT ${ }^{54}$

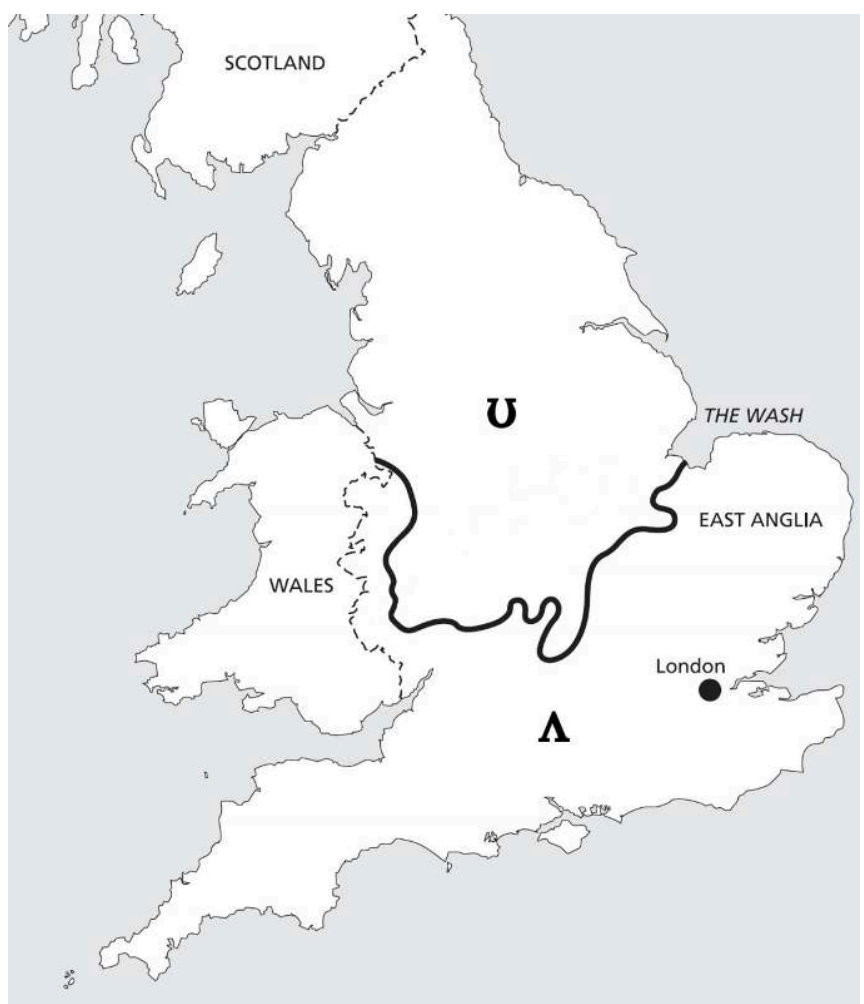

More recently, a number of sociolinguists have studied the emergence of a supralocal pan-Northern variety in England ${ }^{55}$. In addition to the aforementioned features, this variety is characterized by monophthongs in FACE and GOAT (/e:/ and /o:/ respectively), both of which are realized with diphthongs in the South (/eI/ and /əv/ respectively, see figure 6). Watt ${ }^{56}$ argues that these monophthongs are usually considered as modern Northern variants by Northern speakers, which explains the gradual disappearance of local Northern variants - that are limited to a small geographical area - in favour of the supralocal ones. Other works suggest, however, that not all Northern varieties behave in the same way in that respect, as some varieties seem to show no indication of levelling towards these pan-Northern monophthongs, like Manchester for instance ${ }^{57}$.

Figure 6: FACE isogloss (Trudgill 1999: 63) 


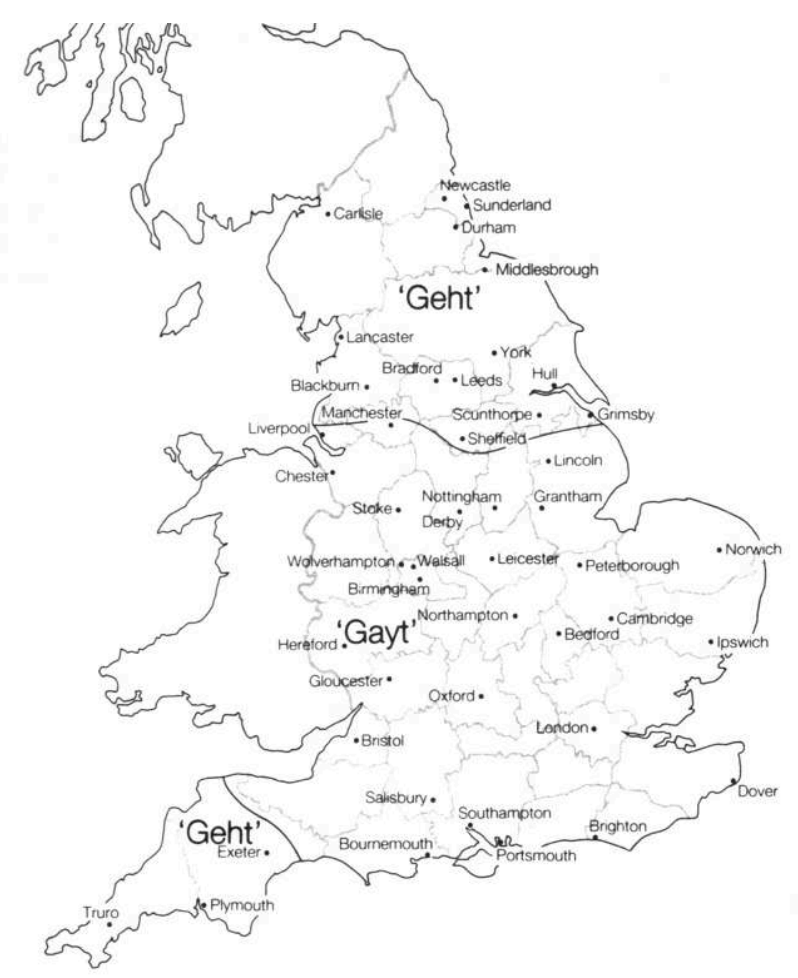

Let us now examine how several characters from GoT are depicted accent-wise and analyze whether actors/actresses have adopted (or, when relevant, discarded) these features. In order to do so, we shall include time stamps in our footnotes to refer the reader to the exact moment one character (in the show) or actor/actress (in real life) pronounces an interesting feature in a given resource ${ }^{58}$.

\subsubsection{The Northern}

Sean Bean is well-known for retaining his Yorkshire accent in a number of his performances ${ }^{59}$ : as a variety from the Middle North ${ }^{60}$, his accent ticks all the boxes of a Northern accent, so to speak. Bean exhibits a rounded STRUT vowel (she's a wonderful woman $^{61}$, when we were younger ${ }^{62}$ ), a short vowel in ВАTH (he stood fast ${ }^{63}$, ask for advice $e^{64}$ ) and monophthongs in both FACE (the blades ${ }^{65}$, the first film I made ${ }^{66}$, what age is Sean $B e a n^{67}$ ) and GOAT (what school did S.B. go to ${ }^{68}$, politicians quoting lines ${ }^{69}$ ). These features are also present in Ned Stark's speech: you have my blood ${ }^{70}$, you're a funny man ${ }^{71}$ (same vowel as FОот); the man who passes the sentence ${ }^{72}$, half a mind to go with you ${ }^{73}$ (short vowel in $\mathrm{BATH})$; your grace $\boldsymbol{e}^{74}$, when serving was safe $\boldsymbol{e}^{75}$ (monophthongs in FACE); you should have asked me twenty years ago ${ }^{76}$, you rode him down ${ }^{77}$ (monophthongs in GOAT).

Richard Madden's Scottish accent shows some similarities with Sean Bean's, most notably monophthongs in FACE and GOAT (I got that phone call which was great $^{78}$ ) and a short vowel in ВАтН (asked my agent for an advance ${ }^{79}$ ). He does, however, have an opposition between FOOT and STRUT, as the comparison of the following phrases makes clear: so, very lucky ${ }^{80}$; a little cult, niche show ${ }^{81}$; and took the picture ${ }^{82}$. As Robb Stark, he aims for a generally Northern accent and avoids the Scottish characteristics that are not found in the latter, such as rhoticity (compare do you find the easiest or hardest ${ }^{83}$ with we'll talk about it first thing in the morning ${ }^{84}$ ) and glide clusters in WH-words ${ }^{85}$ (compare what are your tips for auditioning ${ }^{86}$ with he doesn't know what's happening ${ }^{87}$ ). For

TV/Series, $18 \mid 2020$ 
the same purpose, he has kept monophthongs in FACE and GOAT (in the rain ${ }^{88}$, don't ever say that ${ }^{89}$; let him go $^{90}$, he's starting to know $e^{91}$ ) and a short vowel in BATH (the last time $e^{92}$ ), but his character now shows no opposition between FOOT and STRUT (clutching my leg ${ }^{93}$, and courage ${ }^{94}$; compare with his vowel in why is that good ${ }^{95}$ ).

Hailing from London, Kit Harington's own variety is closer to SSBE. Contrary to Sean Bean and Richard Madden, he uses, in his native accent, clear diphthongs for GOAT and FACE: the audition for Jon Snow ${ }^{96}, \mathbf{n o}, \mathbf{n o}, \mathbf{n o}^{97}$; this girl I was sort of dating at the time, and it was late at night ${ }^{98}$, it weighs a ton ${ }^{99}$. As is typical of SSBE speakers, the vowel of STRUT is unrounded and much more open than the vowel of FOOT: compare his STRUT vowel in we don't need trouble ${ }^{100}$ and I got up and said no, no no, you can't, you can't call her that, get up ${ }^{101}$ to that of FОот in whether it was good ${ }^{102}$ or she looked at me $e^{103}$. He also exhibits ВАTHbroadening: anyone will ask $\mathbf{k}^{104}$, in the cast $^{105}$. In the role of Jon Snow, the most striking Northern features adopted are probably his vowel of STRUT (there are five pups ${ }^{106}$, when you wake $\mathbf{u p}^{107}$ ) and his use of monophthongs in GOAT (no ${ }^{108}$, you do not know, no one knows $\left.^{109}\right)$, though the actor also uses a shorter vowel in BATH words compared to real life (to seat a bastard in their midst ${ }^{110}$ ). However, he seems to have kept a diphthong in FACE (if you're not afraid ${ }^{111}$, the wall's no place for cowards ${ }^{112}$ ).

Let us turn to the other half of the Stark family, though we are leaving aside Bran and Rickon Stark: the former uses the same variety as his sisters, notably Sansa, and the latter has very few lines in the first season, or even in the show as a whole. Both Sophie Turner and Maisie Williams are native speakers of SSBE: as expected, they have diphthongs in FACE and GOAT (this is fake $\boldsymbol{e}^{113}$, as far as I know $\mathbf{w}^{114}$, and I get paid for it what an amazing show ${ }^{115}$; I'm kind of just waiting for someone to come on stage ${ }^{116}, \mathrm{No}^{117}$ ), an unrounded vowel in STRUT (he's really fun ${ }^{118}$; my mother ${ }^{119}$ ) and a long vowel in BATH (I've always asked my mum ${ }^{120}$; and a half-brother ${ }^{121}$ ).

Michelle Fairley, on the other hand, is from Northern Ireland, but her accent is not quite typical of Irish varieties. While most accents in Ireland are rhotic (working-class Dublin English is the main exception), Fairley's own accent is actually variably rhotic: compare her pronunciation of Catelyn Stark ${ }^{122}$ and an integral part of $i t^{123}$. She also has diphthongs in FACE and GOAT (great mates ${ }^{124}$; let it flow $^{125}$ ), which is not a feature of Northern Ireland, though these variants may be found in varieties from the South of Ireland (and obviously, in SSBE). She also exhibits an opposition between FOOT and STRUT (compare cushions ${ }^{126}$ and so much $^{127}$ ).

64 All these features are found in the speech of the three characters played by the actresses: Sansa (ugly ${ }^{128}$, have to wait ${ }^{129}$, say no ${ }^{130}$, so fast ${ }^{131}$ ), Arya (messed up anyway ${ }^{132}$, you've got to go $^{133}$, bastard $^{134}$ ) and Catelyn (another woman's son ${ }^{135}$, the raven ${ }^{136}$, you can always say no ${ }^{137}$, the last hand ${ }^{138}$ ). We shall come back to the fact that not all members of the Stark family speak the same variety later on (\$3.3\& §4).

\subsubsection{The Southern}

65 The Lannisters may be the most diverse family when it comes to the origins of the actors and actresses who portray them (\$2.4). Only Cersei is portrayed by an actress whose native variety is SSBE: both the character and the actress have diphthongs in FACE and GOAT (as Cersei: you were never afraid ${ }^{139}$, down the road ${ }^{140}$; as Lena: not giving anything away ${ }^{141}, \boldsymbol{n o}^{142}$ ), BATH-broadening (compare Cersei's the last thing ${ }^{143}$ with Lena's 
last year ${ }^{144}$ ) and an unrounded open vowel in STRUT, clearly distinct from that of FOOT (compare Cersei's STRUT vowel in lovely country ${ }^{145}$ with that of FOOT in the fever that took him $^{146}$, and Lena's vowels in took a boyfriend home and I was quite young ${ }^{147}$ ).

Cersei's brothers and eldest son, on the other hand, are all played by actors whose native accents correspond to different varieties. Peter Dinklage's accent is close to General American, which means he has diphthongs in FACE (that he made $\boldsymbol{e}^{148}$ ) and GOAT (though its starting point is less central than the SSBE equivalent: you kinda killed my joke $e^{149}$ ), and an opposition between FOOT and STRUT (compare a little extra push ${ }^{150}$ with I mumbled ${ }^{151}$ ). However, his accent is clearly rhotic (the Mayan calendar ${ }^{152}$, later at the bar $^{153}$ ), exhibits T-flapping ${ }^{154}$ (big city ${ }^{155}$ ) and shows no BATH-broadening (the graduating class $\left.{ }^{156}\right)$. As Tyrion, he has an SSBE accent and so Dinklage aims for non-rhoticity (the northern girls ${ }^{157}$, clever girl $^{158}$ ), avoids T-flapping (I've always wanted ${ }^{159}$, the wintery abode ${ }^{160}$ ) and uses a backer vowel in BATH (you're Ned Stark's bastard ${ }^{161}$, you are a bastard though ${ }^{162}$ ). His starting point in GOAT is also much more central, as expected in SSBE (your absence has already been noted ${ }^{163}, \mathbf{g o}^{164}$ ).

Jack Gleeson is a native speaker of Irish English and, as such, is clearly rhotic as well (it's hard to say ${ }^{165}$, the prince regent of banter, kind of lower ${ }^{166}$ ). He also has diphthongs in FACE and GOAT (for a TV show ${ }^{167}$, I didn't know how much people hated the character ${ }^{168}$ ) and seems to have an opposition between FOOT and STRUT, although his STRUT vowel is quite different from SSBE, due to a much closer and backer quality: compare I read the first book $^{169}$ and put more pressure $e^{170}$ to a fun, a fun kind of actor ${ }^{171}$ and I really really loved this you know and all I wanted to be was an actor when I grew up ${ }^{172}$. As Joffrey Baratheon, he aims for a non-rhotic accent (Not your lord and I said 'pick up your sword ${ }^{173}$,' we allow the Northerners too much power ${ }^{174}$ ) and his STRUT vowel is typical of SSBE, as shown in the following excerpts: it's ugly ${ }^{175}$, I'd double their taxes ${ }^{176}$.

Finally, the case of Nikolaj Coster-Waldau is interesting, as he is the only non-native speaker of English discussed so far. One major feature of his English accent is variable rhoticity. In the interview we used to determine the characteristics of his accent, the name Lannister is never pronounced with a final /r/ (though this may be expected considering the majority of non-rhotic accents in GoT), but the word forty-eight ${ }^{177}$ is pronounced as in GA (with T-flapping and a rhotacized vowel). At times, Coster-Waldau can prove inconsistent within the same phrase: who did Jaime Lannister squire for ${ }^{178}$. Other features of his accent include diphthongs in FACE and GOAT (put the phone down, and instantly called a place ${ }^{179}$ ) and an opposition between FOOT and STRUT (compare look like ${ }^{180}$ and the stunt work ${ }^{181}$ ), which is expected if he aims for a GA accent in real life. As Jaime Lannister, he has the same SSBE accent as the other Lannisters: he adopts a nonrhotic pronunciation (I heard you the first time ${ }^{182}$, I don't serve Lord Stark ${ }^{183}$ ) and avoids T-flapping (that was a proper battle ${ }^{184}$, at Winterfell ${ }^{185}$ ), though the influence of his original rhotic accent might still be felt at times, as when he fails to pronounce a linking-r in for hours ${ }^{186}$ or far away ${ }^{187}$ (which would have been expected in a non-rhotic variety).

\subsubsection{The foreign}

Under this heading, we shall mainly discuss characters from Essos, the other continent in the GoT world, and Dorne, the southernmost kingdom in Westeros. 
70 Essos seems relatively complex from a linguistic perspective, which is not surprising given the sheer size of this continent: apart from the Common Tongue of Westeros (used as a "lingua franca", \$2.4), the Dothraki language and several dialects of Valyrian are spoken there. The first two characters presented to the audience as Essosi, who come across as having a distinctive foreign accent through evocation (\$3), are Syrio Forel and Shae. Both characters have (variably) rhotic accents, with Syrio Forel's most common realization of $/ \mathrm{r} /$ being an alveolar trill ("rolled" / $\mathrm{r} /$ ): your dancing master, Syrio Forel ${ }^{188}$. Though Shae's accent can reasonably be interpreted as Sibel Kekilli's natural accent in English ${ }^{189}$, Miltos Yerolemou, who plays Syrio Forel, has a completely different natural (non-rhotic) accent in English ${ }^{190}$.

71 However, not all Essosi characters have a uniform accent. Let us recall that Lord Varys is from Essos, even though he uses an SSBE accent (Conleth Hill is from Northern Ireland). Talisa Maegyr (Robb Stark's wife), who is from Volantis, and Illyrio Mopatis, the prince-merchant from Pentos who arranges Daenerys's marriage to Khal Drogo, also use similar, non-rhotic accents.

One explanation could be that characters from noble Essosi houses or, in the case of Varys, who are close to power, use the same Common Tongue variety as the Lannisters. Yet, further investigation shows that this is not the case: Doreah, sold as a slave by her mother when she was nine, and who later becomes one of Daenerys's handmaidens, has an SSBE accent ${ }^{191}$. Precise geographical origin within Essos does not seem to correlate with accent either: Syrio Forel's accent is nothing like Tycho Nestoris's SSBE accent ${ }^{192}$, while Salladhor Saan's accent ${ }^{193}$ differs from that of Varys or Doreah.

The cultural gap between Dorne and the rest of the Seven Kingdoms is also reflected linguistically. While there are virtually no rhotic varieties in the rest of Westeros, the Martells, Ellaria, and the Sand Snakes all exhibit a rhotic accent: without Doran we have no army to march against the Lannisters ${ }^{194}$ (notice the realization of / $r$ / as an alveolar tap $[c]$ in Doran), your brother was murdered and you sit here in the water gardens ${ }^{195}$ (though brother is pronounced as it would be in a non-rhotic variety), that is no murder ${ }^{196}$, the war ended right here when your father's army took the city ${ }^{197}$. This is a deliberate choice as most of the actors and actresses are native speakers of non-rhotic varieties: both Alexandre Siddig and Indira Varma have SSBE-like non-rhotic accents in real life (idiotic dictators ${ }^{198}$, stay your course ${ }^{199}$ ). Pedro Pascal is the main exception, as his accent is GA, though he doesn't seem to use taps in his native accent (contrary to his character, as in Rhaegar Targaryen ${ }^{200}$ ).

Despite the apparent mix of accents used by the characters hailing from these two regions, it is worth noting that no Essosi or Dornish character uses a Northern accent.

\subsection{A paradoxical portrait: triggering sociolinguistic evaluations of the characters}

GoT seems rather shrewd in its use of the pan-Northern and pan-Southern phonetic and phonological characteristics to anchor the show geographically when it is plainly anachronistic in its use of non-rhoticity to anchor it historically. How can it therefore be both geographically accurate and historically wrong? We claim that it is because GoT is linguistically trapped in between modernity, which challenges it to portray accents and dialects as authentically as possible, and conventions, which dictate that "historical" movies or TV series should feature non-rhotic accents. In other words, the 
show is bound to inconsistency as it mostly needs to be anchored at the sociolinguistic level.

As Brian Wheeler relates ${ }^{201}$ : “'A New York accent wouldn't work,' Dinklage [...] recently explained to the Calgary Herald. 'It doesn't sound right." But what does it mean to sound "right"? And based on whose judgement? The notion seems awfully relative and subjective, and yet that is where we reach the core complexity of the show's accent choices and touch on its fundamentally paradoxical nature (\$4).

People may have no idea where the accents come from exactly or what their precise characteristics are, which will not prevent them from having an opinion about how they "sound" or what social features and personality traits they associate with them. Certainly the idea that there are "right" and "wrong" accents in the depiction of a specific imaginative world implies that people have attitudes regarding language and therefore expectations in terms of how it should be represented. We shall refer to Sherif ${ }^{202}$ here:

When we talk about attitudes, we are talking about what a person has learned in the process of becoming a member of a family, a member of a group, and of society that makes him [sic] react to his social world in a consistent and characteristic way, instead of a transitory and haphazard way.

78 Attitudes are therefore based on what speakers experience in their everyday interactions with others and refer to what they project of the identity and character of people who have similar accents to or different accents from their own. In that sense, reactions to how other people speak create expectations in terms of how people with similar geographical origins or social profiles should be depicted on screen. In turn, seeing certain categories of people systematically represented with specific accents in TV or movie productions reinforces the initial attitudes speakers may have had. In other words, speakers, and so viewers, are immersed in linguistic ideology (Milroy 2001), which is both informed by what happens in the real world and by what is shown on screen of people's linguistic practices. It is both taught and learnt in everyday as well as in fictional interactions - which means that linguistic representation feeds linguistic ideology which subsequently feeds the representation again, in a full circle.

That is exactly what Lippi-Green has shown of the depiction of villains in Disney's animated films ${ }^{203}$, who are systematically portrayed with non-American (hence "foreign") accents, and of female characters in traditional roles with standard pronunciations. Both depictions bear some truths: anything foreign can easily be construed as scary and therefore dangerous or evil, while scientific studies have in fact established that female speakers tend to be linguistically more conservative and use more standard and prestigious forms than male speakers ${ }^{204}$.

However, both depictions are also oversimplifications that participate in creating stereotypes which are then used and expected in fictional representation. We quote Tajfel here on the concept of "stereotyping":

Stereotypes arise from a process of categorization. They introduce simplicity and order where there is complexity and nearly random variation. They can help us cope only if fuzzy differences between groups are transmuted into clear ones, or new differences created where none exist.

[...] in each relevant situation we shall achieve as much stereotyped 
simplification as we can without doing unnecessary violence to the fact (our emphases) ${ }^{205}$.

81 This form of discrimination (in both its acceptations of recognizing a difference between accents and being unfairly biased in favour or against an accent) might be the last socially acceptable one as it allows speakers to belong, to exclude and, most importantly, to consciously perform and unconsciously betray their identities in any given social context. That is true in real life and in fiction as well: pan-Northern and pan-Southern phonological and phonetic characteristics are simplifications but they allow viewers to categorize characters geographically and are also "shortcut[s] to characterization" 206 as they have viewers associate qualities and flaws with those characters as well. GoT's originally and apparently geographical compass is very much, or even more so, a moral one.

Let us take the example of Sean Bean/Ned Stark again who, despite the fact that he was only present in season 1 , has an everlasting impact on the show in terms of characterization as Cersei reminds us when, in the dragon pit (S07E07), she tells Jon Snow "I ask it only of Ned Stark's son. I know Ned Stark's son will be true to his word". Beyond the character's actions and decisions, we claim that it is his Northern accent, identifiable as non-standard and not that of the Lannisters, that allows "to pit the honest Starks in the north against the duplicitous Lannisters in the south" ${ }^{207}$. It is associated with sincerity, simplicity (notably through its working-class connotations), a lack of interest in power, "with toughness and a more 'authentic' brand of masculinity" ${ }^{208}$. On the contrary, SSBE is associated with trickery, sophistication, a lust for power and hypocrisy:

As George Orwell surmises in The Road to Wigan Pier, '[t]he Northerner has "grit", he is grim, "dour", plucky, warm-hearted, and democratic; the Southerner is snobbish, effeminate, and lazy'209.

These instinctive sociolinguistic evaluations, which have been largely documented ${ }^{210}$, can account for some accent performances in GoT that might have been otherwise interpreted as inconsistent. For instance, Robert Baratheon's Northern accent in season 1, which does not exactly make geographical sense as he was born in Storm's End, in the South of Westeros, can be motivated, at the sociolinguistic level, to make him an odd figure to sit on the throne and closer to the Northern values of unsophistication and trustworthiness embodied by Ned Stark, with whom he has shared his childhood in the Vale. In a sort of domino effect, his initially unsettling Northern accent allows to portray Joffrey Baratheon, Robert's eldest son who speaks with an SSBE accent, as having nothing in common with his father - while the audience realizes that Robert is in fact not his father - when Robb Stark is depicted as Ned's true son.

In the same way, one can wonder why Ygritte, the Wildling Jon Snow falls in love with in Season 2, does not have a Scottish accent - Rose Leslie, a native speaker of SSBE, could have performed this accent in the same way that she had to perform a Northern accent - which would make sense from a geographical perspective (\$2.2 \& 2.3). However, from a sociolinguistic one, a Scottish accent would have introduced complexity where a Northern continuum is successful in suggesting the proximity of values between the two characters - and more generally Jon Snow's kinship with the Free Folk, with whom he rides North in the show's final scene (S08E06) - who are both proud Northerners. 
Earlier (\$3.2.1), we mentioned the Stark family not being phonologically homogeneous, which can again make sense in terms of characterization: in season one, Jon Snow and Robb Stark spend their time with Ned while Sansa and Arya are closer to Catelyn, who was not born a Stark - as a Tully, her origins lie in Riverrun, which is located further south, much closer to King's Landing. That her accent should be closer to the Lannisters' thus comes as no surprise. This can also be accounted for in terms of female characters using more standard and prestigious variants.

Finally, let us have a look at two characters who have often been described, in articles or on fan forums (\$0), as "wanderers" in terms of accent performance - namely Ser Davos Seaworth and Lord Petyr Baelish. The latter was born and bred in the South. At the beginning of season 1, he is Master of Coin in the capital, and consequently Aidan Gillen performs an SSBE accent, which is both consistent with where the character lives and with where he is from. However, season after season, his accent starts wandering as his allegiances keep shifting. A YouTube compilation ${ }^{211}$ notably allows to observe the SSBE basis slipping "back" to the actor's rhotic Dublin accent. Again, this can be motivated so as to portray Baelish as an "uncategorizable" character who is extremely unreliable, which 7 seasons of the show do confirm.

As for Davos, he was born in Flea Bottom, the poorest part of King's Landing, and was a smuggler before joining Stannis Baratheon. In one scene ${ }^{212}$ (S03E10), we can see him talking with Gendry, Robert's illegitimate son who is also from Flea Bottom. Interestingly, Liam Cunningham, who is also from Dublin, performs all the major Northern characteristics (no FOOT/STRUT split, monophthongs in GOAT) when the actor playing Gendry does not exhibit them (FOOT/STRUT split, diphthongs in FACE and GOAT). This could be interpreted as a major inconsistency, and yet can make sense from a sociolinguistic perspective: Gendry has never left Flea Bottom when Davos, as a former smuggler, is portrayed as a traveler. What is more, his Northern characteristics bring him closer to the values embodied by the Starks, which is illustrated by Davos' allegiance to and friendship with Jon Snow in the last seasons.

In sum, it seems that, in the world of GoT, the "sociolinguistics of performance" 213 trumps historical and geographical accuracy, that characterization can take precedence over consistency.

\section{Discussion - the fine art of characterization and stereotyping}

Although GoT can be reproached for being linguistically inconsistent or unmotivated, it can also be praised for being linguistically true to life and actually authentic. Indeed, it is the very nature of language, and so accents, to be inconsistent, moving things. Depicting a Northern block versus a Southern block versus a foreign block with respectively uniform accents, and no variation whatsoever, would have made for very dull tectonics where nuances were much needed to provide relief to places and depth to plot and characters. Let us remind the reader that not even actors and actresses in real life are consistent in their accent "performances" (\$3.2).

In Coupland's words, "[a]uthenticity matters", and "[t]here is also a convincing case to be made that language is every bit as much a means of achieving authenticity as it is a means to discrediting it" ${ }^{214}$. Here again we touch on the paradoxical nature of language 
and so the combined aporia and success of the representation of language, of the aesthetics of authenticity in film and TV series. By showcasing non-rhotic accents, GoT is historically inaccurate but geographically effective; by featuring constructed languages, inconsistent foreign accents and a range of British accents, GoT can be said to be Eurocentric but not monolingual; and by including idiosyncratic linguistic profiles, such as Davos and Baelish, GoT proves hybrid but not chaotic. That is, by being part of the high fantasy legacy at the same time as it is aiming to become a mainstream TV series adaptation, the show frees itself from some sociolinguistic constraints but upholds others, as though stuck in between modernity and conservatism, originality and clichés, and therefore proves both authentic and counterfeit, bold and irenic.

91 We here hope to show that sociolinguistic studies, especially from the phonological and phonetic angle, can be complementary to other approaches to the TV series genre and to individual shows. In fact, our reflection on the paradoxical nature of the aesthetics of linguistic authenticity used in GoT can echo and support Hassler-Forest's reflection on the show's gentrification of the fantasy genre:

Game of Thrones' discursive authenticity as an example of the cultural logic of gentrification resides not only in the many paratextual reassurances that the show is faithful to its literary source. It is also and perhaps even more visible in its uncompromising dedication to premium cable's familiar kind of 'most objectionable programming' involving sex and violence. [...] But while some of the most noticeable characteristics of traditional fantasy fiction have been tweaked or altered to adapt to the show's envisioned audience, Game of Thrones' rewriting of genre conventions leaves the most ideologically problematic building blocks largely intact ${ }^{215}$. that it mostly features white characters in a proto-European setting, it gives them anachronistic non-rhotic accents. While it provides strong roles for female characters (especially Arya, Sansa and Daenerys), it "continuously fills up the screen with naked female bodies subjected to the male gaze ${ }^{216}$ " and mostly gives them standard, conservative accents. Though it revisits the "British as villain" cliché by exhibiting almost exclusively non-rhotic accents, it still mostly associates SSBE with duplicity and an evil lust for power. The ode to the North that the show puts forward, all the more so as "the pack survives" in the end, seems to sanction the fact that grittiness and authenticity are paradoxical commodities in the TV series adaptation.

At the same time, such a broad spectrum of accents had seldom been presented to so many different ears from around the world, hence creating a myriad of potentially diverse sociolinguistic interpretations. In the end, the kaleidoscopic depiction of accents that GoT offers is indeed problematic, but also definitely enjoyable and, we claim, as close to authentic as one could possibly get in such a massively popular production. 


\section{BIBLIOGRAPHY}

ALGEO, John, “The Two Streams: British and American English”, Journal of English Linguistics, Vol. 19, No. 2, 1986, p. 269-284.

AURTHUR, Kate, “The 'Game of Thrones' series finale scored a ratings record for HBO”, Buzzfeed, May $20^{\text {th }}, 2019$.

BARANOWSKI, Maciej, TURTON, Danielle, “Manchester English”, in Researching Northern Englishes, ed. Raymond Hickey, Amsterdam and Philadelphia, John Benjamins, 2015, p. 293-316.

BEAL, Joan, "English Dialects in the North of England: Phonology", in Varieties of English. Volume 1: The British Isles, ed. Bernd Kortmann and Clive Upton, Berlin, De Gruyter, 2008, p. 122-144.

BELL, Allan, GIBSON, Andy, "Staging language: An introduction to the sociolinguistics of performance", Journal of Sociolinguistics, Vol. 15, No. 5, 2011, p. 555-572.

BERGLUND, Hanna, Stereotypes of British Accents in Movies: A Speech Analysis of Character Types in Movies with British Accents, Bachelor thesis, Hamstad University, 2017.

BLEICHENBACHER, Lukas, "Linguistic Replacement in the Movies", Poznań Studies in Contemporary Linguistics, Vol. 44, No. 2, 2008, p. 179-196.

BORDWELL, David, Narration in the fiction film, London, Methuen, 1985.

BRITAIN, David, “Supralocal Regional Dialect Levelling”, in Language and Identities, ed. Carmen Llamas and Dominic Watt, Edinburgh, Edinburgh University Press, 2010, p. 193-204.

CHAMBERS, Jack K., TRUDGILL, Peter, Dialectology, $2^{\text {nd }}$ edition, Cambridge, Cambridge University Press, 1998.

CHATELLIER, Hugo, Nivellement et contre-nivellement phonologique à Manchester : étude de corpus dans le cadre du projet PAC-LVTI, Doctoral thesis, Université Toulouse Jean Jaurès, 2016.

COUPLAND, Nikolas, “Sociolinguistic authenticities”, Journal of Sociolinguistics, Vol. 7, No. 3, 2003, p. $417-431$.

CRUTTENDEN, Alan, Gimson's Pronunciation of English, $8^{\text {th }}$ edition, London and New York, Routledge, 2014.

DURAND, Jacques, PRZEWOZNY, Anne, "La phonologie de l'anglais contemporain : usages, variétés et structure”, Revue française de linguistique appliquée, Vol. 17, No. 1, p. 25-37, 2012.

EDDS, Robin, “One thing you might not know about the map from 'Game of Thrones”, Buzzfeed, July $28^{\text {th }}, 2016$.

EKMAN, Stefan, Here Be Dragons: Exploring Fantasy Maps and Settings, Middletown, Connecticut, Wesleyan University Press, 2013.

FLOOD, Alison, "George RR Martin: 'When I began A Game of Thrones I thought it might be a short story”, The Guardian, November $10^{\text {th }}, 2018$.

FULLERTON, Huw, "Sean Bean reveals his lasting impact on the characters of Game of Thrones", Radio Times, March $19^{\text {th }}, 2018$.

GILES, Howard, "Evaluative reactions to accents", Educational Review, Vol. 22, No. 3, 1970, p. 211-227. 
HASSLER-FOREST, Dan, “Game of Thrones - Quality Television and the Cultural Logic of Gentrification”, TV/Series, No. 6, 2014, p. 160-177.

HARRIS, Siân, "Sharper, Better, Faster, Stronger: Performing Northern Masculinity and the Legacy of Sean Bean's Sharpe”, Journal of Popular Television, Vol. 4, No. 2, 2016, p. 239-251.

KRISTIANSEN, Gitte, "Social and linguistic stereotyping: A cognitive approach to accents", Estudios Ingleses de la Universidad Complutense, No. 9, 2001, p. 129-145.

LABOV, William, The social stratification of English in New York City, Washington DC Center for Applied Linguistics, 1966.

LASKOWSKI, Amy, “The languages of Game of Thrones”, BU Today, July 12 2017.

LIEN, Yngvild Audestad, Game of Thrones: a game of accents?: a sociolinguistic study of the representation of accents in HBO's television series, Master's thesis, Norges teknisknaturvitenskapelige universitet, 2016.

LIPPI-GREEN, Rosina, English with an Accent: Language, Ideology and Discrimination in the U.S, London \& New York, Routledge, 1997.

LIPPI-GREEN, Rosina, English with an Accent, New York, Routledge, 2012.

LUNDERVOLD, Lene, Harry Potter and the different accents: a sociolinguistic study of language attitudes in Harry Potter and Game of Thrones, Master's thesis, University of Bergen, 2013.

LUU, Chi, "Very British villains (and other Anglo-Saxon attitudes to accents)", JSTOR Daily, January $18^{\text {th }}, 2017$.

MARTIN, George R.R., “George R.R. Martin's inspiration for 'A Game of Thrones', The Huffington Post, March 26 ${ }^{\text {th }}, 2013$.

MILROY, James, "Language ideologies and the consequences of standardization", Journal of Sociolinguistics, Vol. 5, No. 4, 2001, p. 530-555.

NAVARRO, Sylvain, Le "r" en anglais : Histoire, phonologie et variation, Dijon, Éditions Universitaires de Dijon, 2016.

O'FLAHERTY, Kate, “Here's why that Game of Thrones illegal download probably contains malware", Forbes, April $2^{\text {nd }}, 2019$.

ORWELL, George, The Road to Wigan Pier, London, Penguin Classics, 2001.

READ, Max, "What is going on with the accents in Game of Thrones?, Gawker, June $5^{\text {th }}, 2013$.

SALTER, Jessica, “Game of Thrones: interview with George R.R. Martin”, The Telegraph, March $25^{\text {th }}, 2013$.

SHERIF, Muzafer, "Introduction", in Attitude, ego-involvement, and change, ed. Carolyn W. Sherif and Muzafer Sherif, New York, Wiley, 1967.

STOLWORTHY, Jacob, “Game of Thrones: How long you've spent watching the opening title sequence", The Independent, July $26^{\text {th }}, 2017$.

STUART-SMITH, Jane, LAWSON, Eleanor, SCOBBIE, James, "Derhoticisation in Scottish English: a sociophonetic journey”, in Advances in Sociophonetics, ed. Chiara Celata and Silvia Calamai, Amsterdam, John Benjamins, 2014, p. 57-94.

SUDBURY, Andrea and Jennifer Hay, "The fall and rise of /r/: Rhoticity and /r/-sandhi in early New Zealand English", University of Pennsylvania Working Papers in Linguistics, Vol. 8, No. 3, 2002. 
TAJFEL, Henri, “Cognitive Aspects of Prejudice”, Journal of Social Issues, Vol. 25, No. 4, 1969, p. 79-97.

TAYLOR, Chris, “Why the accents in “Game of Thrones' make no sense”, Mashable, November $29^{\text {th }}$, 2017.

TRUDGILL, Peter, "Sex, covert prestige and linguistic change in the urban British English of Norwich", Language in Society, Vol. 1, No. 2, 1972, p. 179-195.

TRUDGILL, Peter, On Dialect, Oxford, Basil Blackwell Publisher Limited, 1983.

TRUDGILL, Peter, The Dialects of England, $2^{\text {nd }}$ edition, Oxford, Blackwell, 1999.

TZANELLI, Rodhanti, "From Game of Thrones to game of sites/sights: Reconfiguring a transnational cinematic node in Ireland's e-tourism", in Event Mobilities: Politics, Place and Performance, ed. Kevin Hannam, Mary Mostafanezhad and Jillian Rickly, Abingdon, Routledge, 2016.

VIOLLAIN, Cécile and Hugo Chatellier, "De petits corpus pour une grande base de données sur l'anglais oral contemporain : quels enjeux à la lumière du programme PAC ?", Corpus, Vol. 18, 2018.

WATSON, Kevin and Lynn Clark, "Exploring listeners' real-time reactions to regional accents", Language Awareness, Vol. 24, No. 1, 2015, p. 38-59.

WATT, Dominic, “'I don't speak with a Geordie accent, I speak, like, the Northern accent': Contactinduced levelling in the Tyneside vowel system", Journal of Sociolinguistics, Vol. 6, No. 1, 2002, p. 44-63.

WELLS, John C., Accents of English, 3 volumes, Cambridge, Cambridge University Press, 1982.

WELLS-LASSAGNE, Shannon, "High Fidelity: Adapting Fantasy Novels to the Small Screen", TV/

Series, No. 6, 2014, p. 109-122.

WHEELER, Brian, “Why are Fantasy World Accents British?”, BBC News, March 30 $0^{\text {th }}, 2012$.

WILLIAMS, Joel, “Mainstream finally believes fantasy fans”, CNN, March $30^{\text {th }}, 2012$.

\section{NOTES}

1. www.pacprogramme.net

2. Jacques Durand, Anne Przewozny, "La phonologie de l'anglais contemporain : usages, variétés et structure", Revue française de linguistique appliquée, Vol. 17, No. 1, 2012, p. 25-37; Cécile Viollain and Hugo Chatellier, "De petits corpus pour une grande base de données sur l'anglais oral contemporain : quels enjeux à la lumière du programme PAC ?", Corpus, Vol. 18, 2018.

3. https://www.hbo.com/game-of-thrones/cast-and-crew, consulted May $23^{\text {rd }}, 2020$.

4. https://crea.parisnanterre.fr/projet-les-nords-833486.kjsp, consulted May $23^{\text {rd }}, 2020$.

5. Jacob Stolworthy, "Game of Thrones: How long you've spent watching the opening title sequence", The Independent, July $26^{\text {th }}, 2017$, https://www.independent.co.uk/arts-entertainment/ tv/news/game-of-thrones-season-7-opening-titles-sequence-ramin-djawadi-a7861601.html, consulted May $23^{\text {rd }}, 2020$.

6. https://www.youtube.com/watch?v=wpImt0KILE4.

7. https://www.youtube.com/watch?v=TZE9gVF1QbA.

8. Rodhanti Tzanelli, "From Game of Thrones to game of sites/sights: Reconfiguring a transnational cinematic node in Ireland's e-tourism", in Event Mobilities: Politics, Place and 
Performance, ed. Kevin Hannam, Mary Mostafanezhad and Jillian Rickly, Abingdon, Routledge, 2016.

9. Chris Taylor, "Why the accents in 'Game of Thrones' make no sense", Mashable, November $29^{\text {th }}$, 2017, https://mashable.com/2017/11/29/game-of-thrones-accents-guide-british/?europe=true, consulted May $23^{\text {rd }}, 2020$.

10. Yngvild Audestad Lien, Game of Thrones: a game of accents?: a sociolinguistic study of the representation of accents in HBO's television series, Master's thesis, Norges teknisknaturvitenskapelige universitet, 2016.

11. We will obviously shed light on this notion in the next section but here, "linguistic show" is to be understood as a show which showcases linguistic phenomena and relies on the linguistic dimension as an essential component of its universe.

12. Max Read, "What is going on with the accents in Game of Thrones?", Gawker, June $5^{\text {th }}, 2013$, https://gawker.com/what-is-going-on-with-the-accents-in-game-of-thrones-485816507, consulted May $23^{\text {rd }}, 2020$.

13. Lene Lundervold, Harry Potter and the different accents: a sociolinguistic study of language attitudes in Harry Potter and Game of Thrones, Master's thesis, University of Bergen, 2013.

14. Joel Williams, "Mainstream finally believes fantasy fans", CNN, March $30^{\text {th }}, 2012$, https:// edition.cnn.com/2012/03/30/living/mainstream-finally-believes-fantasy-fans/index.html, consulted May $23^{\text {rd }}, 2020$.

15. Kate Aurthur, "The 'Game of Thrones' series finale scored a ratings record for HBO”, Buzzfeed, May 20 $0^{\text {th }}, 2019$, https://www.buzzfeednews.com/article/kateaurthur/game-of-thrones-seriesfinale-record-ratings, consulted May $23^{\text {rd }}, 2020$.

16. Kate O'Flaherty, “Here's why that Game of Thrones illegal download probably contains malware", Forbes, April $2^{\text {nd }}, 2019$, https://www.forbes.com/sites/kateoflahertyuk/2019/04/02/ game-of-thrones-downloads-probably-contain-malware-heres-how-to-avoid-it/\#4ef7b95365ea, consulted May $23^{\text {rd }}, 2020$.

17. http://www.gameofthrones.com/game-of-thrones/season-8/episode-6/histories/1/robertsrebellion, consulted May $23^{\text {rd }}, 2020$.

18. Dan Hassler-Forest, "Game of Thrones - Quality Television and the Cultural Logic of Gentrification", TV/Series, No. 6, 2014, p. 166-167.

19. Stefan Ekman, Here Be Dragons: Exploring Fantasy Maps and Settings, Middletown, Connecticut, Wesleyan University Press, 2013.

20. http://www.gameofthrones.com/game-of-thrones/season-8/episode-6/map/location/8/ castle-black, consulted May $23^{\text {rd }}, 2020$.

21. http://www.bbc.co.uk/newsbeat/article/32620706/westeros-from-game-of-thrones-createdon-google-maps-by-redditor, May $7^{\text {th }}, 2015$, consulted May $23^{\text {rd }}, 2020$.

22. Shannon Wells-Lassagne, "High Fidelity: Adapting Fantasy Novels to the Small Screen", TV/ Series, No. 6, 2014, p. 113.

23. https://www.huffpost.com/entry/george-rr-martins-inspiration_n_2945193? guccounter=1\&guce_referrer

=aHR0cHM6Ly93d3cuZ29vZ2xlLmNvbS8\&guce_referrer_sig=AQAAAEI8cX19HFlAsPQeX1TIGRGrpDNX1u5ZvqZDoFBObujQQh7g2ib_thwn Jp1V5pXIAe9nCm0xal0Jp2WTDy4BZLfQByo21WkDf5-dNB9l8Ripfo8tnl7J8sB, March 26, 2013, consulted May $23^{\text {rd }}, 2020$.

24. Alison Flood, “George RR Martin: 'When I began A Game of Thrones I thought it might be a short story", The Guardian, November $10^{\text {th }}, 2018$, https://www.theguardian.com/books/2018/ nov/10/books-interview-george-rr-martin, consulted May $23^{\text {rd }}, 2020$.

25. Jessica Salter, "Game of Thrones: interview with George R.R. Martin", The Telegraph, March $25^{\text {th }}$, 2013, https://www.telegraph.co.uk/culture/tvandradio/game-of-thrones/9945808/Gameof-Thrones-Interview-with-George-RR-Martin.html, consulted May 23 ${ }^{\text {rd }}, 2020$. 
26. The Lord of the Seven Kingdoms is also King of the Andals and the First Men.

27. Amy Laskowski, "The Languages of Game of Thrones", BU Today, July 12 ${ }^{\text {th }}$, 2017, http:// www.bu.edu/articles/2017/game-of-thrones-languages/, consulted May $23^{\text {rd }}, 2020$.

28. Robin Edds, “One thing you might not know about the map from 'Game of Thrones"', Buzzfeed, July $28^{\text {th }}, 2016$, https://www.buzzfeed.com/robinedds/these-maps-prove-that-westeros-is-basedon-the-british-isles, consulted May $23^{\text {rd }}, 2020$.

29. Wells-Lassagne, p. 112.

30. Laskowski, art. cit.

31. See Erik Singer's website for a dialect coach's perspective on many actors' and actresses' linguistic performances: https://www.eriksinger.com, consulted May $23^{\text {rd }}, 2020$.

32. https://www.youtube.com/watch?v=tBRH5s2lsxc, consulted May $23^{\text {rd }}, 2020$.

33. https://www.youtube.com/watch?v=n4TdEdaMwo4, consulted May $23^{\text {rd }}, 2020$.

34. Huw Fullerton, "Sean Bean reveals his lasting impact on the characters of Game of Thrones", Radio Times, March 19 ${ }^{\text {th }}, 2018$, https://www.radiotimes.com/news/tv/2018-03-19/sean-beanreveals-his-lasting-impact-on-the-characters-of-game-of-thrones/, consulted May $23^{\text {rd }}, 2020$.

35. Lukas Bleichenbacher, "Linguistic Replacement in the Movies", Poznań Studies in Contemporary Linguistics, Vol. 44, No. 2, 2008, p. 179-180.

36. Bleichenbacher, p. 186.

37. John Algeo, "The Two Streams: British and American English", Journal of English Linguistics, Vol. 19, No. 2, 1986, p. 269-284.

38. We use the symbol $[r]$ to broadly represent the pronunciation of an orthographic $<r>$, whatever its actual phonetic quality which, for the varieties of English we are concerned with here, would most likely correspond to an alveolar approximant $([\mathrm{I}])$.

39. Other terms such as "Received Pronunciation" or "General British" are also used in the literature, and we refer the reader to Cruttenden (2014) for a complete description as well as an overview of the latest developments of this variety.

40. See Andrea Sudbury and Jennifer Hay, "The fall and rise of /r/: Rhoticity and /r/-sandhi in early New Zealand English", University of Pennsylvania Working Papers in Linguistics, Vol. 8, No. 3, 2002; Jane Stuart-Smith, Eleanor Lawson and James Scobbie, "Derhoticisation in Scottish English: a sociophonetic journey", in Advances in Sociophonetics, ed. Chiara Celata and Silvia Calamai, Amsterdam, John Benjamins, 2014, p. 57-94.

41. John C. Wells, Accents of English, 3 volumes, Cambridge, Cambridge University Press, 1982, p. 213-222.

42. Peter Trudgill, The Dialects of England, $2^{\text {nd }}$ edition, Oxford, Blackwell, 1999, p. 55.

43. Sylvain Navarro, Le " $r$ " en anglais : Histoire, phonologie et variation, Dijon, Éditions Universitaires de Dijon, 2016, p. 55-60.

44. Lundervold, p. 54-55.

45. Rosina Lippi-Green, English with an Accent, New York, Routledge, 2012.

46. Hanna Berglund, Stereotypes of British Accents in Movies: A Speech Analysis of Character Types in Movies with British Accents, Bachelor thesis, Hamstad University, 2017.

47. Chi Luu, "Very British villains (and other Anglo-Saxon attitudes to accents", JSTOR Daily, January $18^{\text {th }}, 2017$, https://daily.jstor.org/very-british-villains-and-other-anglo-saxon-attitudesto-accents/, consulted May $23^{\text {rd }}, 2020$.

48. Wells, p. 349-350.

49. Wells, p. 350-351; Joan Beal, "English Dialects in the North of England: Phonology", in Varieties of English. Volume 1: The British Isles, ed. Bernd Kortmann and Clive Upton, Berlin, De Gruyter, 2008, p. 129-130.

50. The keywords written in small capitals are lexical sets. We refer the reader to Wells (1982) for further reading.

51. Wells, p. 196-197 \& 203-206. 
52. Adapted from Jack K. Chambers and Peter Trudgill, Dialectology, $2^{\text {nd }}$ edition, Cambridge, Cambridge University Press, 1998, p. 107.

53. Wells, p. 351-352.

54. Adapted from Chambers and Trudgill, p. 107.

55. David Britain, "Supralocal Regional Dialect Levelling”, in Language and Identities, ed. Carmen Llamas and Dominic Watt, Edinburgh, Edinburgh University Press, 2010, p. 193-204.

56. Dominic Watt, “'I don't speak with a Geordie accent, I speak, like, the Northern accent': Contact-induced levelling in the Tyneside vowel system", Journal of Sociolinguistics, No. 6, 2002, p. 56-67.

57. Maciej Baranowski and Danielle Turton, "Manchester English", in Researching Northern Englishes, ed. Raymond Hickey, Amsterdam and Philadelphia, John Benjamins, 2015, p. 293-316; Hugo Chatellier, Nivellement et contre-nivellement phonologique à Manchester : étude de corpus dans le cadre du projet PAC-LVTI, Doctoral thesis, Université Toulouse Jean Jaurès, 2016.

58. We shall mostly use YouTube videos in this article as they are accessible to everyone and do not infringe copyright laws.

59. Siân Harris, "Sharper, Better, Faster, Stronger: Performing Northern Masculinity and the Legacy of Sean Bean's Sharpe”, Journal of Popular Television, Vol. 4, No. 2, 2016, p. 239-251.

60. John C. Wells, Accents of English, 3 volumes, Cambridge, Cambridge University Press, 1982, p. 364-365.

61. https://www.youtube.com/watch?v=nsHpj5FJXjI\&t=17, consulted May 23 ${ }^{\text {rd }}, 2020$.

62. https://www.youtube.com/watch?v=nsHpj5FJXjI\&t=33, consulted May $23^{\text {rd }}, 2020$.

63. https://www.youtube.com/watch?v=nsHpj5FJXjI\&t=392, consulted May $23^{\text {rd }}, 2020$.

64. https://www.youtube.com/watch?v=nsHpj5FJXjI\&t=406, consulted May $23^{\text {rd }}, 2020$.

65. https://www.youtube.com/watch?v=nsHpj5FJXjI\&t=43, consulted May $23^{\text {rd }}, 2020$.

66. https://www.youtube.com/watch? $\mathrm{v}=\mathrm{nsHpj5FJXjI \& t=65}$, consulted May $23^{\text {rd }}, 2020$.

67. https://www.youtube.com/watch?v=nsHpj5FJXjI\&t=90, consulted May $23^{\text {rd }}, 2020$.

68. https://www.youtube.com/watch?v=nsHpj5FJXjI\&t=97, consulted May $23^{\text {rd }}, 2020$.

69. https://www.youtube.com/watch?v=nsHpj5FJXjI\&t=166, consulted May $23^{\text {rd }}, 2020$.

70. https://www.youtube.com/watch?v=5kRJLO6vT7c\&t=590, consulted May 23 $3^{\text {rd }}, 2020$.

71. https://www.youtube.com/watch?v=5kRJLO6vT7c\&t=1623, consulted May $23^{\text {rd }}, 2020$.

72. https://www.youtube.com/watch?v=5kRJLO6vT7c\&t=185, consulted May $23^{\text {rd }}, 2020$.

73. https://www.youtube.com/watch?v=5kRJLO6vT7c\&t=639, consulted May $23^{\text {rd }}, 2020$.

74. https://www.youtube.com/watch?v=5kRJLO6vT7c\&t=243, consulted May $23^{\text {rd }}, 2020$.

75. https://www.youtube.com/watch?v=5kRJLO6vT7c\&t=1287, consulted May $23^{\text {rd }}, 2020$.

76. https://www.youtube.com/watch?v=5kRJLO6vT7c\&t=650, consulted May $23^{\text {rd }}, 2020$.

77. https://www.youtube.com/watch?v=5kRJLO6vT7c\&t=1075, consulted May $23^{\text {rd }}, 2020$.

78. https://www.youtube.com/watch?v=Tt2tEiCokiw\&t=82, consulted May $23^{\text {rd }}, 2020$.

79. https://www.youtube.com/watch? $\mathrm{v}=\mathrm{Tt} 2 \mathrm{tEiC0kiw \& t=84}$, consulted May $23^{\text {rd }}, 2020$.

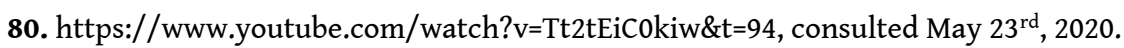

81. https://www.youtube.com/watch?v=Tt2tEiCokiw\&t=20, consulted May $23^{\text {rd }}, 2020$.

82. https://www.youtube.com/watch?v=Tt2tEiCokiw\&t=26, consulted May $23^{\text {rd }}, 2020$.

83. https://www.youtube.com/watch?v=4llnN4EEXWQ\&t=30, consulted May $23^{\text {rd }}, 2020$.

84. https://www.youtube.com/watch? $v=Y b n b y O 4 K y P 0 \& t=247$, consulted May $23^{\text {rd }}, 2020$.

85. Many British English accents, unlike Scottish and Irish, are characterized by what Wells (p. 228) calls "Glide Cluster Reduction". He defines it as: "Pairs such as whine and wine are homophonous in many accents of English. In others, they are distinct, as they were historically: / 'hwaIn/ vs. /'waIn/ etc. The loss of /h/ from the cluster /hw/, which gives whine the same pronunciation as wine, may be referred to as Glide cluster Reduction."

86. https://www.youtube.com/watch?v=4llnN4EEXWQ\&t=7, consulted May $23^{\text {rd }}, 2020$.

87. https://www.youtube.com/watch?v=YbnbyO4KyP0\&t=285, consulted May $23^{\text {rd }}, 2020$. 
88. https://www.youtube.com/watch?v=YbnbyO4KyP0\&t=358, consulted May 23 ${ }^{\text {rd }}, 2020$. 89. https://www.youtube.com/watch? $v=Y$ bnbyO4KyP0\&t=384, consulted May $23^{\text {rd }}, 2020$. 90. https://www.youtube.com/watch? $v=Y$ bnbyO4KyP0\&t=873, consulted May $23^{\text {rd }}, 2020$. 91. https://www.youtube.com/watch?v=YbnbyO4KyP0\&t=1691, consulted May $23^{\text {rd }}, 2020$. 92. https://www.youtube.com/watch?v=YbnbyO4KyP0\&t=268, consulted May 23 ${ }^{\text {rd }}, 2020$. 93. https://www.youtube.com/watch? $v=Y$ bnbyO4KyP0\&t=288, consulted May $23^{\text {rd }}, 2020$. 94. https://www.youtube.com/watch? $v=Y$ bnbyO4KyP0\&t=867, consulted May $23^{\text {rd }}, 2020$. 95. https://www.youtube.com/watch? $v=Y b n b y O 4 K y P 0 \& t=560$, consulted May $23^{\text {rd }}, 2020$. 96. https://www.youtube.com/watch?v=uzOScm2LXcQ\&t=3, consulted May $23^{\text {rd }}, 2020$.

97. https://www.youtube.com/watch?v=Dy-3FxwVf_M\&t=475, consulted May $23^{\text {rd }}, 2020$. 98. https://www.youtube.com/watch?v=uz0Scm2LXcQ\&t=15, consulted May $23^{\text {rd }}, 2020$. 99. https://www.youtube.com/watch?v=Dy-3FxwVf_M\&t=118, consulted May 23 $3^{\text {rd }}, 2020$. 100. https://www.youtube.com/watch?v=uz0Scm2LXcQ\&t=32, consulted May $23^{\text {rd }}, 2020$. 101. https://www.youtube.com/watch?v=uz0Scm2LXcQ\&t=36, consulted May $23^{\text {rd }}, 2020$. 102. https://www.youtube.com/watch?v=Dy-3FxwVf_M\&t=221, consulted May $23^{\text {rd }}, 2020$. 103. https://www.youtube.com/watch?v=Dy-3FxwVf_M\&t=454, consulted May $23^{\text {rd }}, 2020$. 104. https://www.youtube.com/watch?v=uz0Scm2LXcQ\&t=120, consulted May $23^{\text {rd }}, 2020$. 105. https://www.youtube.com/watch?v=Dy-3FxwVf_M\&t=73, consulted May $23^{\text {rd }}, 2020$. 106. https://www.youtube.com/watch?v=ZqqZSuKrY-U\&t=344, consulted May $23^{\text {rd }}, 2020$. 107. https://www.youtube.com/watch?v=ZqqZSuKrY-U\&t=836, consulted May $23^{\text {rd }}, 2020$. 108. https://www.youtube.com/watch?v=ZqqZSuKrY-U\&t=1706, consulted May $23^{\text {rd }}, 2020$. 109. https://www.youtube.com/watch?v=ZqqZSuKrY-U\&t=3050, consulted May $23^{\text {rd }}, 2020$. 110. https://www.youtube.com/watch?v=ZqqZSuKrY-U\&t=435, consulted May $23^{\text {rd }}, 2020$. 111. https://www.youtube.com/watch?v=ZqqZSuKrY-U\&t=874, consulted May $23^{\text {rd }}, 2020$. 112. https://www.youtube.com/watch?v=ZqqZSuKrY-U\&t=1641, consulted May $23^{\text {rd }}, 2020$. 113. https://www.youtube.com/watch?v=U-10jT03zpQ\&t=216, consulted May $23^{\text {rd }}, 2020$. 114. https://www.youtube.com/watch? $v=a O-n u r 8-O S Y \& t=73$, consulted May $23^{\text {rd }}, 2020$. 115. https://www.youtube.com/watch?v=aO-nur8-OSY\&t=517, consulted May $23^{\text {rd }}, 2020$. 116. https://www.youtube.com/watch?v=TTYOpfGvlwc\&t=12, consulted May $23^{\text {rd }}, 2020$. 117. https://www.youtube.com/watch?v=TTYOpfGvlwc\&t=20, consulted May $23^{\text {rd }}, 2020$. 118. https://www.youtube.com/watch?v=aO-nur8-OSY\&t=468, consulted May $23^{\text {rd }}, 2020$. 119. https://www.youtube.com/watch?v=TTYOpfGvlwc\&t=284, consulted May $23^{\text {rd }}, 2020$. 120. https://www.youtube.com/watch? $v=a O-n u r 8-O S Y \& t=200$, consulted May $23^{\text {rd }}, 2020$. 121. https://www.youtube.com/watch?v=TTYOpfGvlwc\&t=127, consulted May $23^{\text {rd }}, 2020$. 122. https://www.youtube.com/watch? $v=$ mzjf_sNinck\& $t=117$, consulted May $23^{\text {rd }}, 2020$. 123. https://www.youtube.com/watch?v=mzjf_sNinck\&t=152, consulted May $23^{\text {rd }}, 2020$. 124. https://www.youtube.com/watch? $v=$ mzjf_sNinck\&t=270, consulted May $23^{\text {rd }}, 2020$. 125. https://www.youtube.com/watch? $v=$ mzjf_sNinck\&t=146, consulted May $23^{\text {rd }}, 2020$. 126. https://www.youtube.com/watch? $v=$ mzjf_sNinck\& $t=475$, consulted May $23^{\text {rd }}, 2020$. 127. https://www.youtube.com/watch? $v=$ mzjf_sNinck\&t=375, consulted May $23^{\text {rd }}, 2020$. 128. https://www.youtube.com/watch? $v=i 9 H-Z O b h y H g \& t=290$, consulted May $23^{\text {rd }}, 2020$. 129. https://www.youtube.com/watch? $v=i 9 H-Z O b h y H g \& t=303$, consulted May $23^{\text {rd }}, 2020$. 130. https://www.youtube.com/watch? $v=i 9 H-Z O b h y H g \& t=308$, consulted May $23^{\text {rd }}, 2020$. 131. https://www.youtube.com/watch? $v=i 9 H-Z O b h y H g \& t=812$, consulted May $23^{\text {rd }}, 2020$. 132. https://www.youtube.com/watch? $v=-i w 4 D \_B Y o U 0 \& t=419$, consulted May $23^{\text {rd }}, 2020$. 133. https://www.youtube.com/watch?v=-iw4D_BYoU0\&t=666, consulted May $23^{\text {rd }}, 2020$. 134. https://www.youtube.com/watch?v=-iw4D_BYoU0\&t=2036, consulted May 23 ${ }^{\text {rd }}, 2020$. 135. https://www.youtube.com/watch?v=ERHgzPBJVDk\&t=663, consulted May $23^{\text {rd }}, 2020$. 136. https://www.youtube.com/watch?v=ERHgzPBJVDk\&t=234, consulted May $23^{\text {rd }}, 2020$. 137. https://www.youtube.com/watch?v=ERHgzPBJVDk\&t=252, consulted May $23^{\text {rd }}, 2020$. 
138. https://www.youtube.com/watch?v=ERHgzPBJVDk\&t=471, consulted May $23^{\text {rd }}, 2020$. 139. https://www.youtube.com/watch?v=1qvOAS-vT7k\&t=82, consulted May $23^{\text {rd }}, 2020$.

140. https://www.youtube.com/watch?v=1qvOAS-vT7k\&t=1150, consulted May $23^{\text {rd }}, 2020$. 141. https://www.youtube.com/watch?v=ooyqP_RHmPQ\&t=58, consulted May $23^{\text {rd }}, 2020$. 142. https://www.youtube.com/watch?v=ooyqP_RHmPQ\&t=16, consulted May $23^{\text {rd }}, 2020$. 143. https://www.youtube.com/watch?v=1qvOAS-vT7k\&t=738, consulted May $23^{\text {rd }}, 2020$. 144. https://www.youtube.com/watch?v=ooyqP_RHmPQ\&t=44, consulted May $23^{\text {rd }}, 2020$. 145. https://www.youtube.com/watch?v=1qvOAS-vT7k\&t=415, consulted May $23^{\text {rd }}, 2020$. 146. https://www.youtube.com/watch?v=1qvOAS-vT7k\&t=731, consulted May $23^{\text {rd }}, 2020$. 147. https://www.youtube.com/watch?v=ooyqP_RHmPQ\&t=282, consulted May $23^{\text {rd }}, 2020$. 148. https://www.youtube.com/watch? $v=C u E f E v 0 O l s Y \& t=53$, consulted May $23^{\text {rd }}, 2020$. 149. https://www.youtube.com/watch?v=CuEfEv0OlsY\&t=173, consulted May $23^{\text {rd }}, 2020$. 150. https://www.youtube.com/watch?v=CuEfEv0OlsY\&t=305, consulted May $23^{\text {rd }}, 2020$. 151. https://www.youtube.com/watch?v=CuEfEv0OlsY\&t=530, consulted May $23^{\text {rd }}, 2020$. 152. https://www.youtube.com/watch?v=CuEfEv0OlsY\&t=192, consulted May $23^{\text {rd }}, 2020$. 153. https://www.youtube.com/watch?v=CuEfEv0OlsY\&t=295, consulted May $23^{\text {rd }}, 2020$. 154. Wells (p. 248) defines it as follows: "One of the most striking characteristics of American pronunciation to the ears of a non-American is the intervocalic consonant in words such as atom, better, waiting. To English people it sounds like a /d/ rather than a / $t /$. Phonetically it is usually a rapid tap rather than a more deliberate plosive; it is also frequently voiced", hence "tapping", which is symbolized as [r].

155. https://www.youtube.com/watch?v=CuEfEv0OlsY\&t=145, consulted May $23^{\text {rd }}, 2020$. 156. https://www.youtube.com/watch?v=CuEfEv0OlsY\&t=156, consulted May $23^{\text {rd }}, 2020$. 157. https://www.youtube.com/watch?v=fHXjASiDB5g\&t=188, consulted May 23 ${ }^{\text {rd }}, 2020$. 158. https://www.youtube.com/watch?v=fHXjASiDB5g\&t=234, consulted May $23^{\text {rd }}, 2020$. 159. https://www.youtube.com/watch?v=fHXjASiDB5g\&t=315, consulted May $23^{\text {rd }}, 2020$. 160. https://www.youtube.com/watch?v=fHXjASiDB5g\&t=690, consulted May $23^{\text {rd }}, 2020$. 161. https://www.youtube.com/watch?v=fHXjASiDB5g\&t=327, consulted May $23^{\text {rd }}, 2020$. 162. https://www.youtube.com/watch?v=fHXjASiDB5g\&t=335, consulted May $23^{\text {rd }}, 2020$. 163. https://www.youtube.com/watch?v=fHXjASiDB5g\&t=570, consulted May $23^{\text {rd }}, 2020$. 164. https://www.youtube.com/watch?v=fHXjASiDB5g\&t=584, consulted May $23^{\text {rd }}, 2020$. 165. https://www.youtube.com/watch?v=2PUefiJBJQQ\&t=112, consulted May $23^{\text {rd }}, 2020$. 166. https://www.youtube.com/watch?v=2PUefiJBJQQ\&t=146, consulted May $23^{\text {rd }}, 2020$. 167. https://www.youtube.com/watch? $v=2$ PUefiJBJQQ\&t=41, consulted May $23^{\text {rd }}, 2020$. 168. https://www.youtube.com/watch?v=2PUefiJBJQQ\&t=80, consulted May $23^{\text {rd }}, 2020$. 169. https://www.youtube.com/watch? $v=2$ PUefiJBJQQ\&t=88, consulted May $23^{\text {rd }}, 2020$. 170. https://www.youtube.com/watch?v=2PUefiJBJQQ\&t=352, consulted May $23^{\text {rd }}, 2020$. 171. https://www.youtube.com/watch?v=2PUefiJBJQQ\&t=171, consulted May $23^{\text {rd }}, 2020$. 172. https://www.youtube.com/watch?v=2PUefiJBJQQ\&t=331, consulted May $23^{\text {rd }}, 2020$. 173. https://www.youtube.com/watch?v=-KCZfB6BEuE\&t=146, consulted May $23^{\text {rd }}, 2020$. 174. https://www.youtube.com/watch?v=-KCZfB6BEuE\&t=321, consulted May $23^{\text {rd }}, 2020$. 175. https://www.youtube.com/watch?v=-KCZfB6BEuE\&t=248, consulted May $23^{\text {rd }}, 2020$. 176. https://www.youtube.com/watch?v=-KCZfB6BEuE\&t=328, consulted May $23^{\text {rd }}, 2020$. 177. https://www.youtube.com/watch?v=sYSXyxEh8Sc\&t=85, consulted May $23^{\text {rd }}, 2020$. 178. https://www.youtube.com/watch?v=sYSXyxEh8Sc\&t=406, consulted May $23^{\text {rd }}, 2020$. 179. https://www.youtube.com/watch?v=sYSXyxEh8Sc\&t=111, consulted May $23^{\text {rd }}, 2020$. 180. https://www.youtube.com/watch?v=sYSXyxEh8Sc\&t=27, consulted May $23^{\text {rd }}, 2020$. 181. https://www.youtube.com/watch?v=sYSXyxEh8Sc\&t=345, consulted May $23^{\text {rd }}, 2020$. 182. https://www.youtube.com/watch?v=7PLi0vS0kqg\&t=546, consulted May $23^{\text {rd }}, 2020$. 183. https://www.youtube.com/watch?v=7PLi0vS0kqg\&t=1241, consulted May $23^{\text {rd }}, 2020$. 
184. https://www.youtube.com/watch?v=7PLi0vS0kqg\&t=1207, consulted May $23^{\text {rd }}, 2020$.

185. https://www.youtube.com/watch?v=7PLi0vS0kqg\&t=1218, consulted May $23^{\text {rd }}, 2020$.

186. https://www.youtube.com/watch?v=7PLi0vS0kqg\&t=1120, consulted May $23^{\text {rd }}, 2020$.

187. https://www.youtube.com/watch?v=7PLi0vS0kqg\&t=1284, consulted May $23^{\text {rd }}, 2020$.

188. https://www.youtube.com/watch?v=upcWBut9mrI\&t=12, consulted May $23^{\text {rd }}, 2020$.

189. See for example this interview: https://www.youtube.com/watch?v=klZehhI4Ymc, consulted May $23^{\text {rd }}, 2020$.

190. https://www.youtube.com/watch?v=3UYgEx2Px9k, consulted May $23^{\text {rd }}, 2020$.

191. https://www.youtube.com/watch?v=aLlhcjNELnk, consulted May $23^{\text {rd }}, 2020$.

192. https://www.youtube.com/watch?v=HXCfHmUrf68\&t=129, consulted May $23^{\text {rd }}, 2020$.

193. https://www.youtube.com/watch?v=TZxDQ1ZKTVs, consulted May $23^{\text {rd }}, 2020$.

194. https://www.youtube.com/watch?v=spJzn8IxsIk\&t=2022, consulted May $23^{\text {rd }}, 2020$.

195. https://www.youtube.com/watch?v=spJzn8IxsIk\&t=1892, consulted May $23^{\text {rd }}, 2020$.

196. https://www.youtube.com/watch?v=spJzn8IxsIk\&t=1902, consulted May $23^{\text {rd }}, 2020$.

197. https://www.youtube.com/watch?v=fu3wR0LhcDo\&t=224, consulted May $23^{\text {rd }}, 2020$.

198. https://www.youtube.com/watch?v=s4BZz4_ieIc\&t=173, consulted May $23^{\text {rd }}, 2020$.

199. https://www.youtube.com/watch?v=yMtB3TZ0L3Y\&t=23, consulted May $23^{\text {rd }}, 2020$.

200. https://www.youtube.com/watch?v=fu3wRoLhcDo\&t=198, consulted May $23^{\text {rd }}, 2020$.

201. Brian Wheeler, "Why are Fantasy World Accents British?", BBC News, March $30^{\text {th }}, 2012$, https://www.bbc.com/news/magazine-17554816, consulted May $23^{\text {rd }}, 2020$.

202. Muzafer Sherif, "Introduction", in Attitude, Ego-Involvement, and Change, ed. Carolyn W. Sherif and Muzafer Sherif, New York, Wiley, 1967, p. 2, and quoted in Lene Lundervold, Harry Potter and the different accents: a sociolinguistic study of language attitudes in Harry Potter and Game of Thrones, Master's thesis, University of Bergen, 2013, p. 11.

203. Rosina Lippi-Green, English with an Accent, New York, Routledge, 2012.

204. William Labov, The social stratification of English in New York City, Washington DC Center for Applied Linguistics, 1966; Peter Trudgill, "Sex, covert prestige and linguistic change in the urban British English of Norwich", Language in Society, Vol. 1, No. 2, 1972, p. 179-195.

205. Henri Tajfel, “Cognitive Aspects of Prejudice”, Journal of Social Issues, Vol. 25, No. 4, 1969, p. 82-83, and quoted in Gitte Kristiansen, "Social and linguistic stereotyping: A cognitive approach to accents", Estudios Ingleses de la Universidad Complutense, No. 9, 2001, p. 137.

206. Lippi-Green, p. 84.

207. Harris, p. 17.

208. Harris, p. 5.

209. George Orwell, The Road to Wigan Pier, London, Penguin Classics, 2001, p. 101; quoted in Harris, p. 6.

210. Howard Giles, "Evaluative reactions to accents", Educational Review, Vol. 22, No. 3, 1970, p. 211-227; Peter Trudgill, On Dialect, Oxford, Basil Blackwell Publisher Limited, 1983; Kevin Watson and Lynn Clark, "Exploring listeners' real-time reactions to regional accents", Language Awareness, Vol. 24, No. 1, 2015, p. 38-59.

211. https://www.youtube.com/watch?v=os9s_OgC4a8, consulted May $23^{\text {rd }}, 2020$.

212. https://www.youtube.com/watch?v=PUJLUbOavUg, consulted May $23^{\text {rd }}, 2020$.

213. Allan Bell and Andy Gibson, "Staging language: An introduction to the sociolinguistics of performance", Journal of Sociolinguistics, Vol. 15, No. 5, 2011, p. 555-572.

214. Nikolas Coupland, "Sociolinguistic authenticities", Journal of Sociolinguistics, Vol. 7, No. 3, 2003, p. 417.

215. Dan Hassler-Forest, "Game of Thrones - Quality Television and the Cultural Logic of Gentrification", TV/Series No. 6, 2014, p. 172 \& 174.

216. Hassler-Forest, p. 174. 


\section{ABSTRACTS}

When it comes to places and territories, much is at stake in Game of Thrones (henceforth, GoT) as the opening credits, which map out the narrative world of this series, make very clear to the audience. We argue that the accents spoken by the characters are part and parcel of the creation of the GoT universe and greatly contribute to anchoring the show at the historical, geographical and sociolinguistic levels. Indeed, with the advent of dialect coaches, accents have become a paramount component in actors and actresses' performances, which are widely discussed online and evaluated as credible and deserving of awards, or, on the contrary, as completely off target and ridiculous. It consequently should not come as a surprise that GoT is a rich object of investigation for sociolinguists as accents are performed with specific purposes: to bring the audience to a different time (i.e. a pseudo-medieval era), to different places as the characters do not come from the same geographical areas and the plot unfolds over a rather large territory, and to different conclusions as to the moral values and personality traits of the different characters. There are many lay accounts of the actors and actresses' accent performances, but the socio-phonological literature on this issue is still rather scarce. Fundamental research has been conducted into how the discourse features and pronunciation of TV series or cartoon characters reinforce stereotypes and are a shortcut to characterization (Lippi-Green 1997, 2012). However, to our knowledge, no systematic phonological, phonetic and sociolinguistic study of the accents in GoT has been published. This is precisely what we offer to do here.

La carte et le territoire sont au cœur des enjeux propres à Game of Thrones (ci-après GoT), comme le signale très clairement au public le générique qui cartographie longuement l'espace diégétique de la série. Nous défendons ici l'idée que les accents parlés par les personnages sont essentiels à la création de l'univers GoT et contribuent à ancrer la série aux niveaux historique, géographique et sociolinguistique. De fait, avec l'avènement des dialect coaches (ce que l'on pourrait traduire par " conseillers linguistiques »), les accents sont devenus un élément majeur dans l'interprétation des acteurs et actrices, qui est largement commentée en ligne et évaluée comme crédible et digne des plus prestigieuses récompenses ou, au contraire, comme complètement à côté de la plaque et ridicule. Il n'est dès lors pas surprenant que GoT constitue un riche objet d'étude pour les sociolinguistes dans la mesure où les accents sont joués dans des buts précis : transporter les spectateurs dans un autre espace-temps (en l'occurrence une ère pseudo-médiévale), les emmener dans des lieux variés puisque les personnages n'ont pas tous les mêmes origines géographiques et l'histoire se déroule sur un territoire plutôt vaste, et les amener à des conclusions différentes quant aux valeurs morales et aux traits de caractère propres aux différents personnages. Il existe de nombreux avis profanes sur les performances " accentuelles » des acteurs et actrices mais encore très peu de travaux socio-phonologiques dans la littérature sur le sujet. Des recherches essentielles ont été menées, notamment par Lippi-Green (1997, 2012), sur la manière dont les marqueurs de discours et la prononciation dans les dessins animés et les séries télévisées renforcent les stéréotypes socioculturels et servent de raccourcis pour la caractérisation des personnages. Toutefois, à notre connaissance, aucune étude phonologique, phonétique et sociolinguistique systématique des accents dans GoT n'a été publiée. C'est précisément ce que nous nous proposons de faire ici.

Game of Thrones, phonologie, variétés de l'anglais, sociolinguistique, stéréotypes, caractérisation 


\section{INDEX}

Keywords: Game of Thrones, phonology, accents of English, sociolinguistics, stereotyping, characterization

\section{AUTHORS}

\section{CÉCILE VIOLLAIN}

Cécile Viollain est Maîtresse de Conférences en linguistique anglaise à l'Université Paris Nanterre. Elle a un doctorat en socio-phonologie anglaise de l'Université Toulouse Jean Jaurès mené dans le cadre du programme de recherche PAC (www.pacprogramme.net) sur les caractéristiques sociolinguistiques, phonologiques et phonétiques des variétés d'anglais parlées à travers le monde. Cécile Viollain est spécialiste des variétés australasiennes et de l'hémisphère sud. Avec Flore Coulouma, elle a lancé un projet de recherche transdisciplinaire intitulé « Les Nords dans le monde anglophone » au sein du laboratoire CREA de l'Université Paris Nanterre. Cécile Viollain is Associate Professor in English linguistics at Université Paris Nanterre, France. She holds a PhD in socio-phonology from Université Toulouse Jean Jaurès which was conducted within the French PAC programme (www.pacprogramme.net) on the sociolinguistic, phonological and phonetic characteristics of the varieties of English spoken worldwide. Cécile Viollain specializes in the Southern Hemisphere and Australasian varieties. Along with Flore Coulouma, she has launched a transdisciplinary research project named "The Norths in the English-speaking world" within the CREA research laboratory at Université Paris Nanterre.

\section{HUGO CHATELLIER}

Hugo Chatellier est Maître de Conférences en linguistique anglaise à l'Université Paris Nanterre. Il a un doctorat en socio-phonologie anglaise de l'Université Toulouse Jean Jaurès mené dans le cadre du programme de recherche PAC (www.pacprogramme.net) sur les caractéristiques sociolinguistiques, phonologiques et phonétiques des variétés d'anglais parlées à travers le monde. Hugo Chatellier est spécialiste des variétés du nord de l'Angleterre. Avec Flore Coulouma, il a lancé un projet de recherche transdisciplinaire intitulé « Les Nords dans le monde anglophone » au sein du laboratoire CREA de l'Université Paris Nanterre.

Hugo Chatellier is Associate Professor in English linguistics at Université Paris Nanterre, France. He holds a PhD in socio-phonology from Université Toulouse Jean Jaurès which was conducted within the French PAC programme (www.pacprogramme.net) on the sociolinguistic, phonological and phonetic characteristics of the varieties of English spoken worldwide. He specializes in the Northern English varieties. Along with Flore Coulouma, he has launched a transdisciplinary research project named "The Norths in the English-speaking world" within the CREA research laboratory at Université Paris Nanterre. 